\title{
CAUSES OF THE PHENOMENON OF BULLYING AND ITS IMPACTS DURING CORONAVIRUS PANDEMIC IN BAMHA VILLAGE OF EL-AYAT DISTRICT, GIZA GOVERNORATE
}

(Received: 21.4.2021)

By

\author{
M. Y. A. Radwan
}

Department of Rural Sociology, Faculty of Agriculture, Al-Azhar University, Cairo, Egypt

\begin{abstract}
This research aimed to identify the causes of the phenomenon of bullying during Coronavirus pandemic and its impacts from the respondents' point of view, as well as their proposals to overcome it. The research was conducted on 110 respondents. Data were collected through a questionnaire during the May 2020. After that, the data were discharged and analyzed statistically. It was clear from the results that:

- The most important forms of bullying that respondents were exposed to during the Coronavirus pandemic were: boycott and avoiding dealing, spreading rumors about them, ignoring, and offensive looks.

- The most important social causes of bullying were: Low awareness and lack of information, the spread of rumors and misinformation, and deficiencies in the socialization process.

- The most important economic causes were: Living pressures, debts and installments, and low incomes.

- The most important psychological causes of bullying were: Extreme fear of infection and the unknown, fear of losing work, trying to reduce stress, anxiety and panic.

- The most important social impacts were: The negative impact of family relations, boycotting social media, and boycotting friends and family.

- The most important psychological impacts were: depression, anxiety and tension, nervousness and anger, and introversion.

- The most important health impacts were: loss of appetite, digestive system pains, persistent headache, fatigue and constant physical exhaustion, and sleep disturbances.

- The most important suggestions to overcome the phenomenon of bullying were: Activating media role in raising awareness and constantly confronting rumors, activating the role of all competent authorities in dealing with family problems, activating the role of mosques and churches in inculcating and spreading moral values, and working to provide job opportunities and improve the living conditions of rural people.
\end{abstract}

Key words: Bullying, Pandemic, Novel Coronavirus.

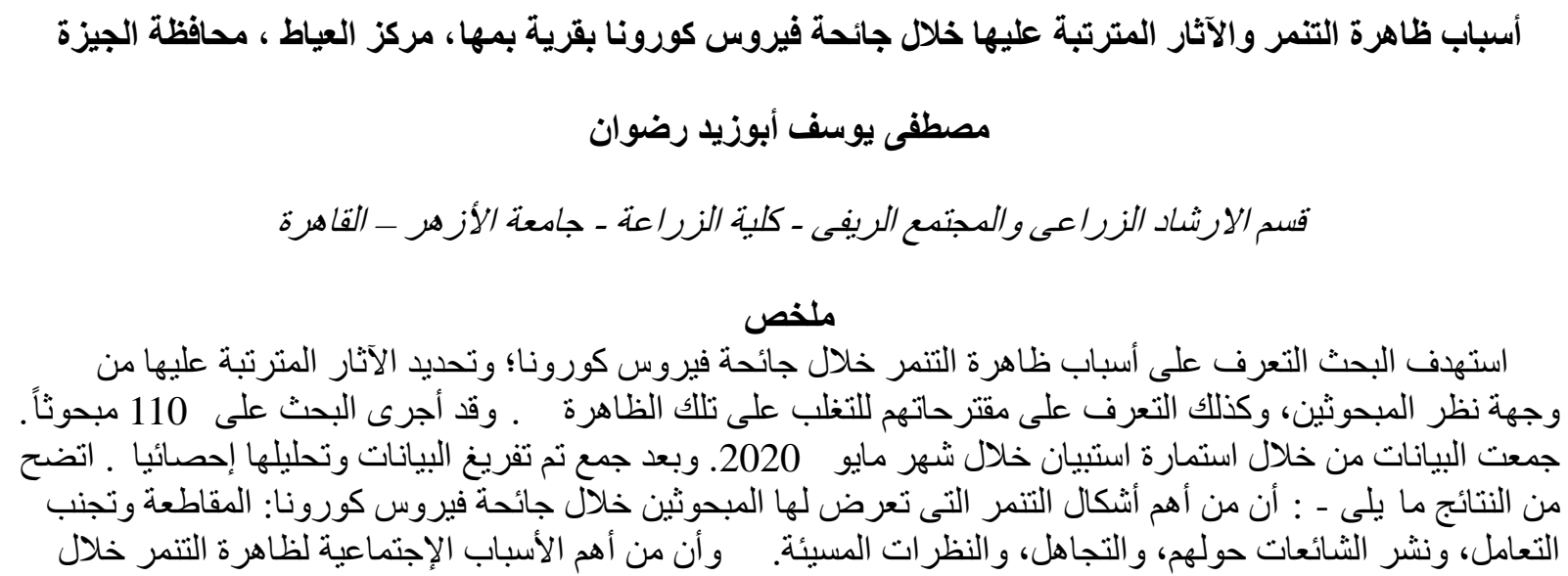


جائحة فيروس كورونا كان: انخفاض الو عى وقلة المعلومات، و انتشار الثائعات و المعلومات الخاطئة، و القصور في عملية

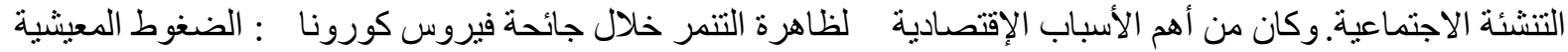

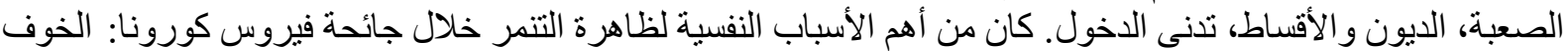

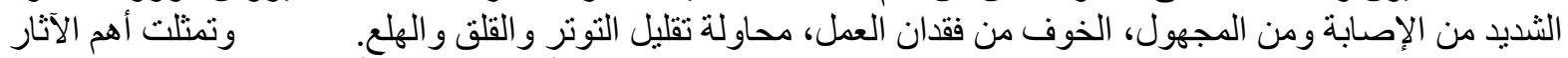

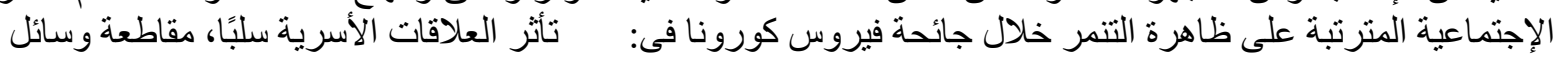

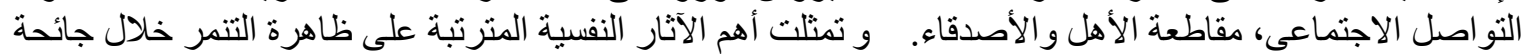

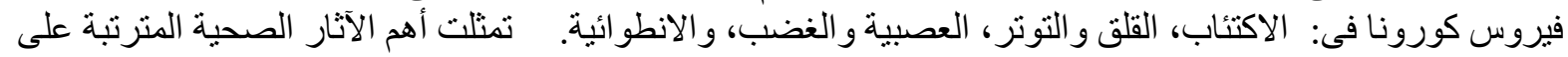

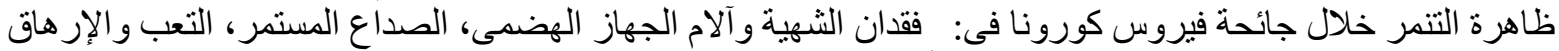

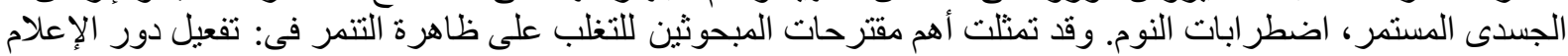

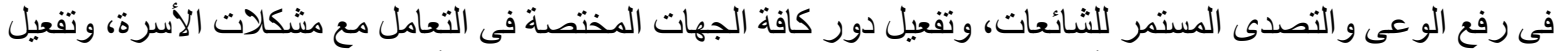

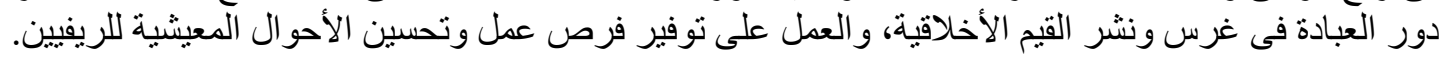

الذين اشتبه في إصابتهم، و الأشخاص العاملون

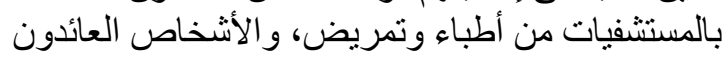

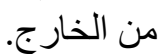
فعلى سبيل المثنال، في الو لايات المتحدة وأوروبا تم الماري

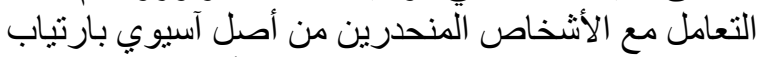

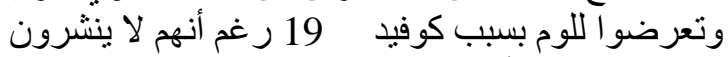

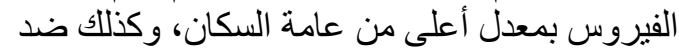

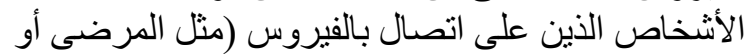

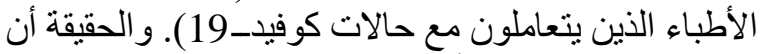
هذه الظاهرة خطيرة، لأن إلقاء اللوم على مجمو عات الات معينة من الناس وتوجيه الإهانة إليهم بسبب جائحة ولائ وبائية أمرٌ

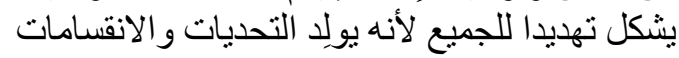
الاجتماعية النى تعيق جهود السيطرة على الجئل الجائحة. وكذللك عانت العديد من البلدان العربية في مقدمنتها

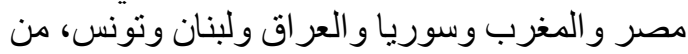

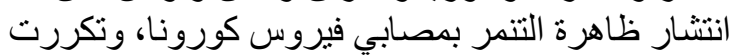

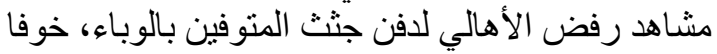
على حياتهر.

ففى مصر بدأنا نلمس خطورة هذه الظاهرة، حيث

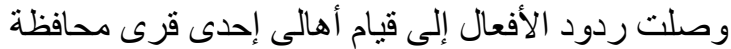

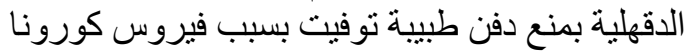

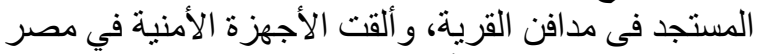

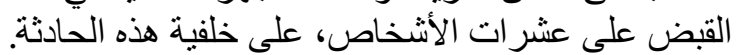

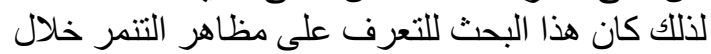

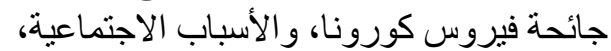

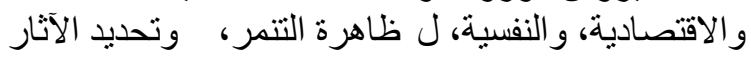

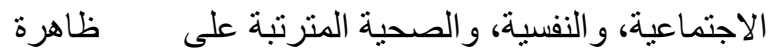

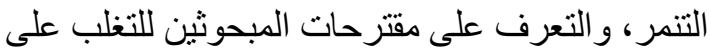
ظاهرة التنمر خلال الأزمات الوبائية.

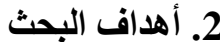

فى ضوء مشكلة البحث السابق عرضها تحددت أهدافه فيما 1 - التعرف على الخصائص الاجتماعية و الاقتصادية لالمبحوثين. 2 - التعرف على أنكال التتمر خلال جائحة فيروس

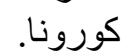

\section{1المقدمة ومشكلة البحث}

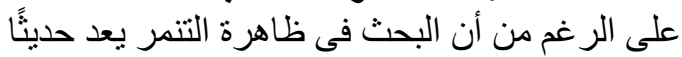

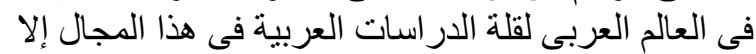

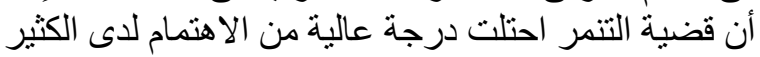

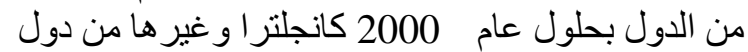

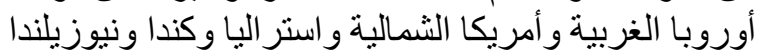

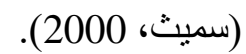

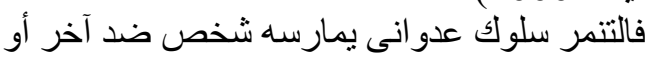

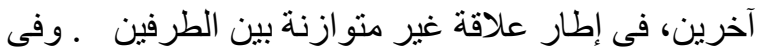

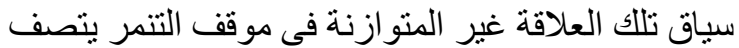

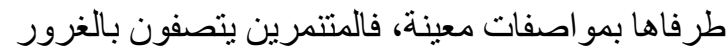

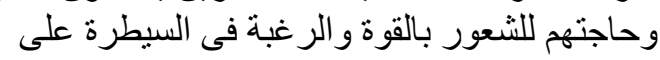

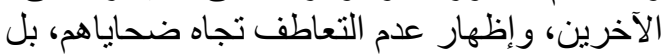

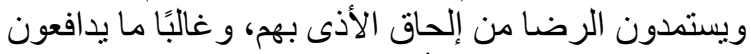

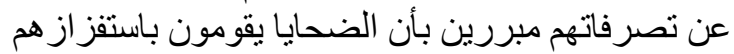

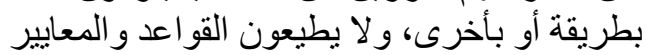

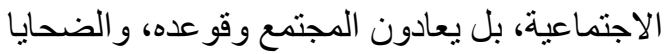

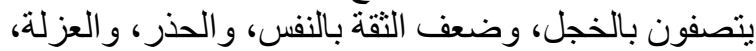

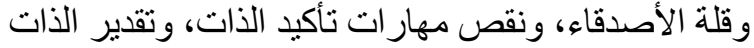
المنخفض، و الضعف الجسدى و النفسى (القحطانى، 2008؛ ليتويلر وبروسك، وليك، 2013 ). وتظهر آثار التنمر السلبية على المتورطين فيه والتى دئى

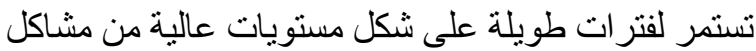

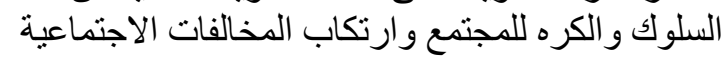

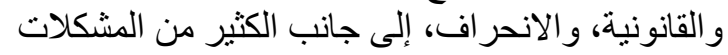

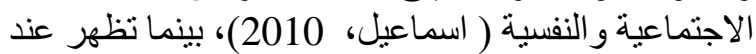

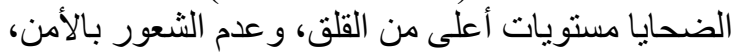

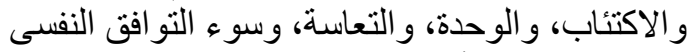

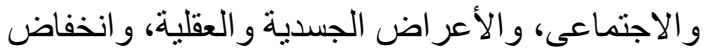
تقدير الذات لديهر، و أحيانًا التفكير الاتنحارى (ناسيل،

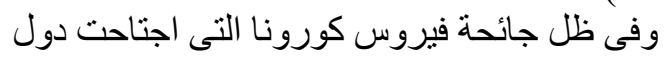

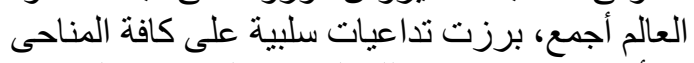

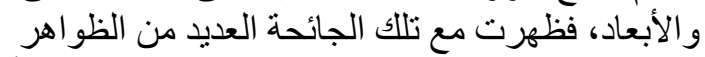

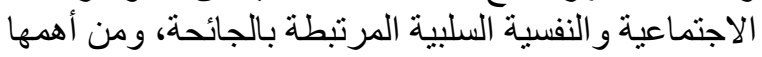

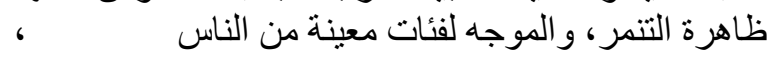
كالأشخاص الذين تأكدت إصابتهم بفيروس كورنة النان 
3.1.3 مفهوم الجائحة

قد صنفت منظمة الصحة العالمية تفني فيروس

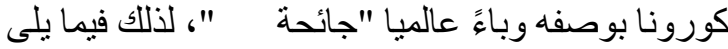
توضيح لمفهوم الجائحة:

الجائحة تعنى الانتشار غير المسيطر عليه، وحين يقترن

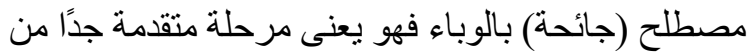
انتشار الوباء و عدم القدرة على التحكم فيه و السيطرة علئه لئهة

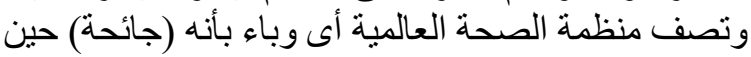

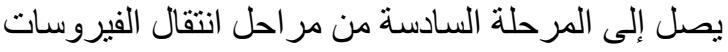

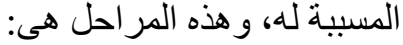
المرحلة الأولى: انتشار الفيروسات داخل الهئ أجسام الحيوانات

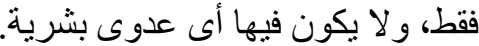
المرحلة الثانية: انتقال الفيروس الحيو الثيو انى إلى الإنسان.

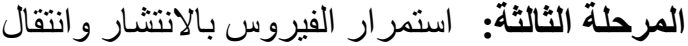
العدوى من إنسان إلى آخر في المجتمع ذاتهاته.

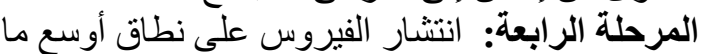
يؤدى إلى زيادة عدد المصابين باله الفئه وبداية اتساعها.

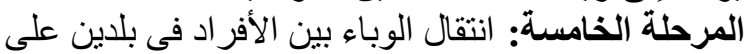
الأقل. - الملة المرحلة السادسة: اجنباح الوباء أقاليم أو قار ات مختلفة،

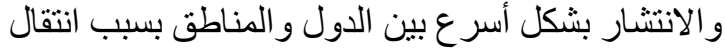
الفيروس مع الإنسان، وفى هذه المرحلة يتم وصف الإن الوباء بأنه ( جائحة ).

\section{3.}

لقد كثرت المدارس والنظريات المفسرة لظاهرة التنمر ، حيث عملت على تفسير العو امل المؤدية إلى حدوثئه

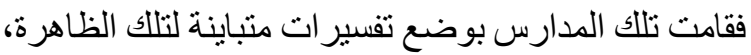
ومن هنا سوف يتم عرض بعض المدارس المن المهمة بشيء من الإيجاز ، وذللك على النحو الآتي: 1.2.3. المدرسة الاجتماعية الإنة الإنية

تتبنى المدرسة الاجتماعية النظرية السلوكية، ونظرية

التعلم الاجتماعي، و هذه نبذة موجزة التهنة عن كل منهما:

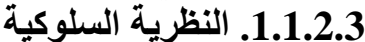

تركز هذه النظرية على أسباب التنمر، وتبرز أهم النقاط النقاط

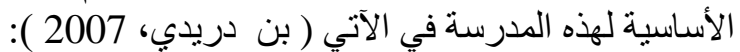

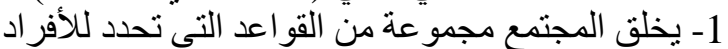
المجالات المقبولة وغير المقبولة بين أنّماط السلوك لكورك

$$
\text { الاجنماعي. }
$$

2-عتبر التتشئة الاجتماعية أهم الأدوات التي يضعها المجتمع لتحقيق أهدافه الضبطية.

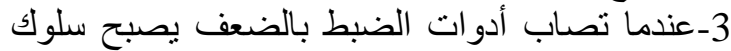

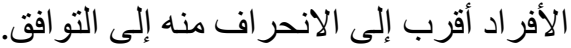

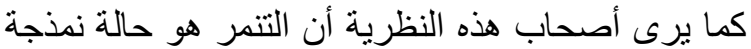

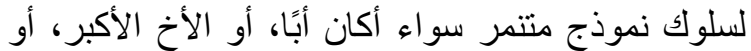

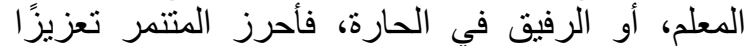

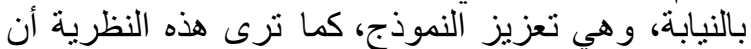

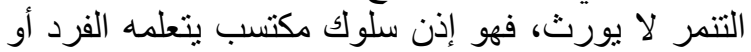

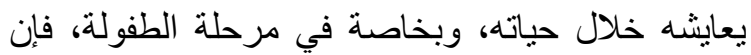

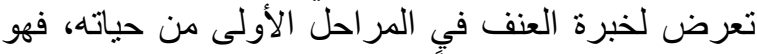
في الغالب سيمارسه لاحقًا مع غيره من الناس، وحتى مع الأل حع
3 - التعرف على الأسباب الاجتماعية، و الاقتصادية،

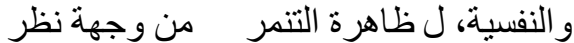

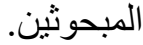

4 - تحديد الآثار الاجتماعية، و النفسية، و الصحية

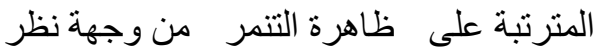

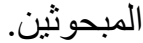

5 - تحديد معنوية العلاقة بين المتغير ات التالية

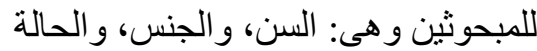
التعليمية، و عدد أفر اد الأسرة، و المهنة، والين والدخل

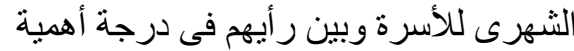

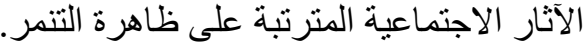

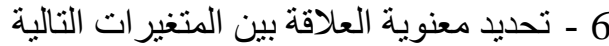

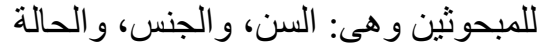

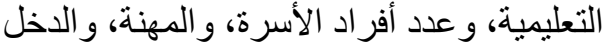
الثهرى للأسرة وبين ر أيهم فى درجة الأيرة أهمية النية

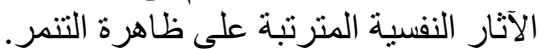
7 - تحديد معنوية العلاقة بين المتغير ات التئن التالية

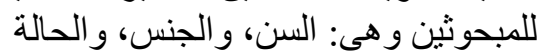
التعليمية، و عدد أفر اد الأسرة، والمنين والمهنة، و والدخل

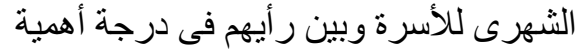
الآثار الصحية المترنبة على ظعاهرة التنمر.

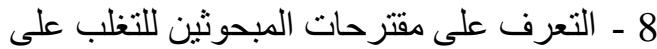
ظاهرة التنمر خلال الأزمات الوبائية.

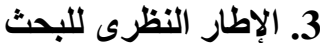

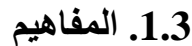

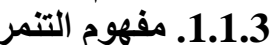

يعد التتمر شكلاً من أثكال العدو ان، وتهديدًا يحدث

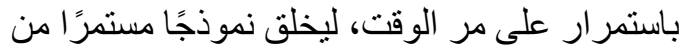

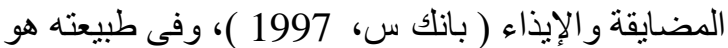

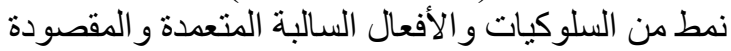

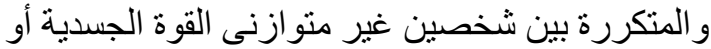
النفسية أو كليهما (ألواياس، 1995؛ فريمان وك الئن ارول،

2 - 2.1.3.شكال التنمر

يمكن أن يتخذ التتمر أشكالاً عدة؛ فيمكن أن يكون ذلك التكان

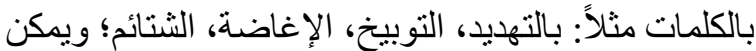

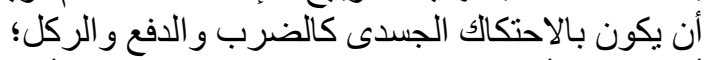

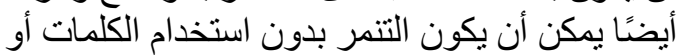

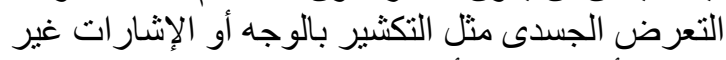

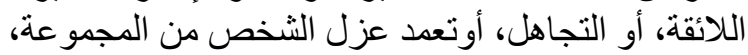

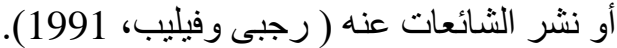

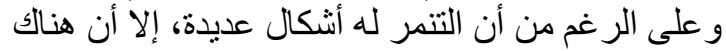

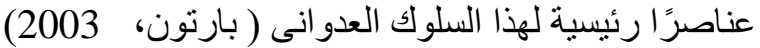

يكيكون متعددًا سو اء كان جسديًا أو لفظيًا أو بشكل غير

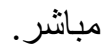

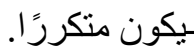

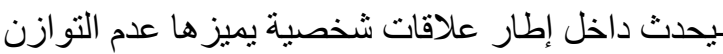
فى القوة سواءً كان حقيقيًا أو معنويًا. 
استخدام العنف عند شح الموارد و المصادر التي يمتلكها".

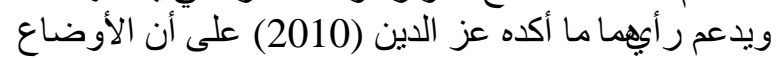

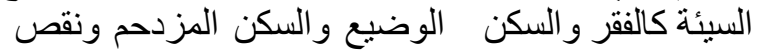

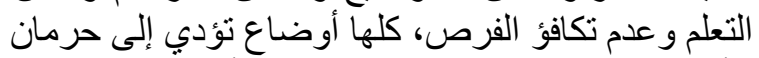

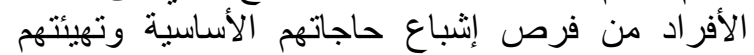

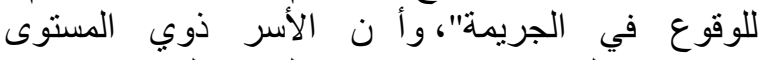

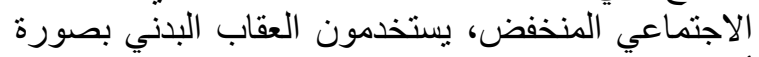

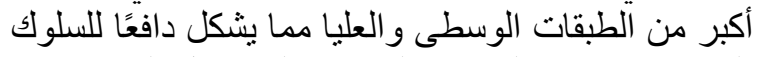

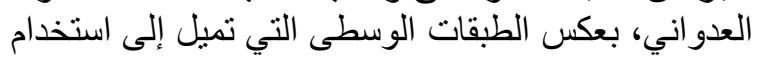

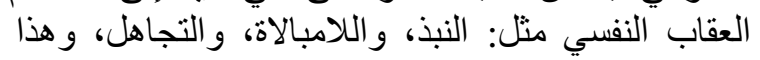
يفسر زيادة نسبة السلوك الاجرامى بين الطبقات الدنيا بشكل مرتفع.

\subsection{3. المدرسة التحليلية ( النفسية)}

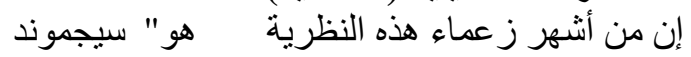

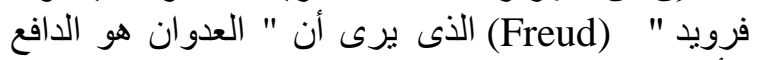

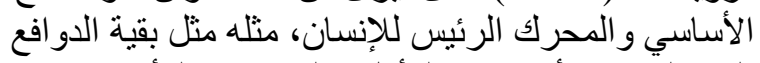

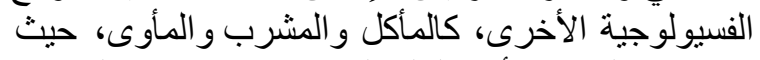

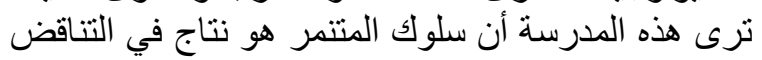

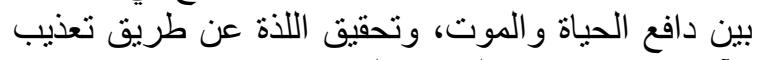

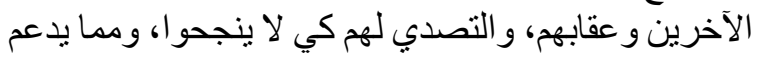

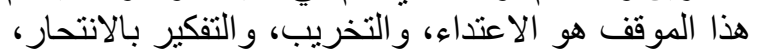

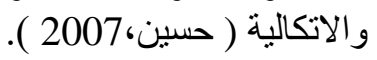

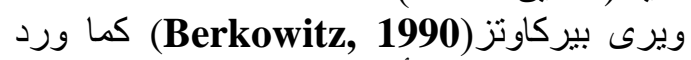
لاى عز الدين ( 2010 ) أن حالات الإحباط الثنديد نؤدي وري إلى ظهور قدر معين من العدو انية الذي يعتمد الإحساط على كمية

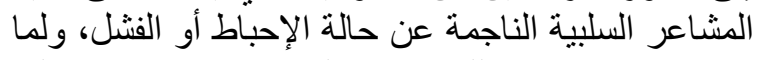

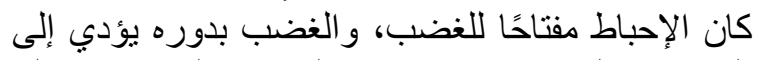

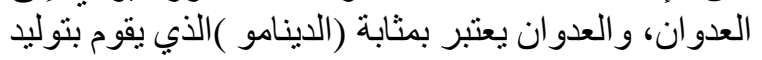

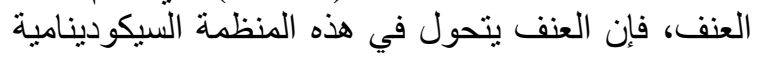

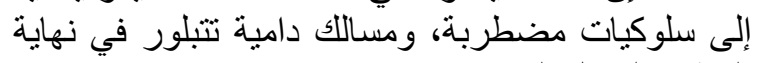
المطاف لتصل إلى الانتقام. وتتمثل جوانب القوة في المدرسة التحليلية بأنها تقدم

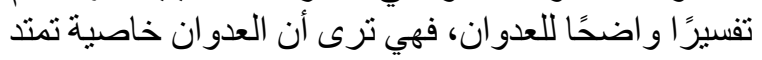

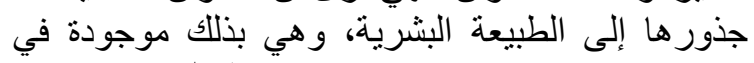

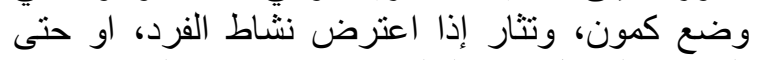

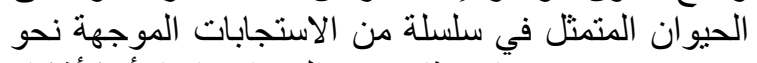

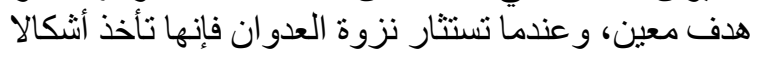

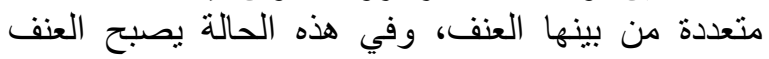

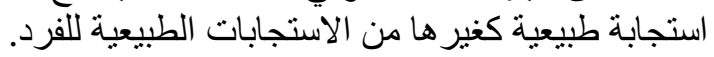

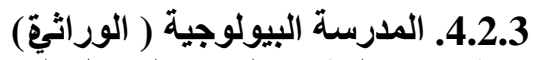

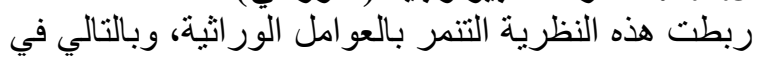

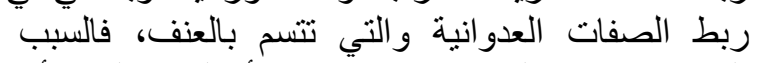
الو اضح في هذه النظرية هي صنفات متأصلية في الفرد نأناتيها

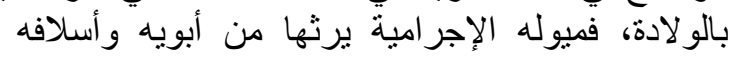

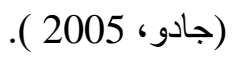

حيث يرى البعض أن العدوان سلوك بدائي له جذور

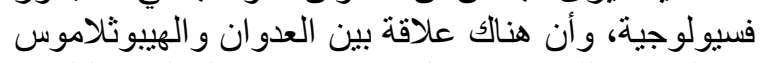

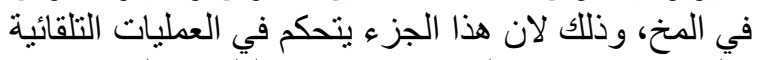

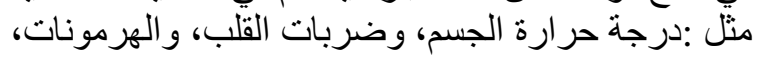
وأن العمليات الدافعية، والانفعالية هي الأخرى تتأثر أيضًا

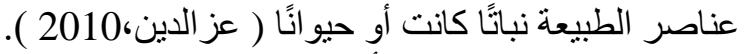

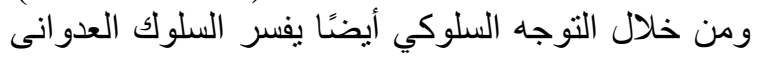

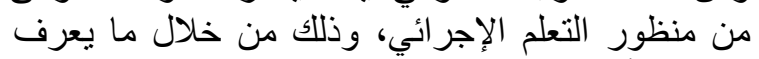
بقانون الأثر الذي توصل إلبه سكينر ، ويستند القانون على الإنى

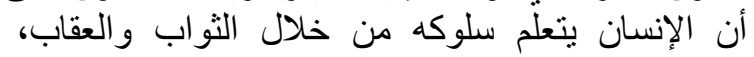

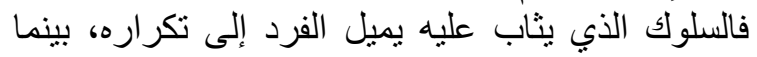

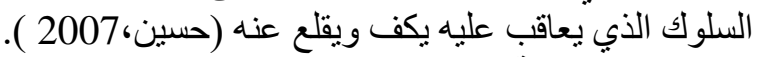

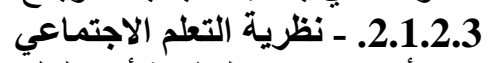

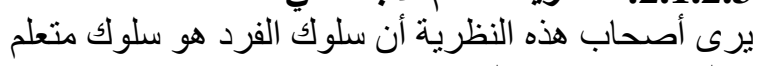

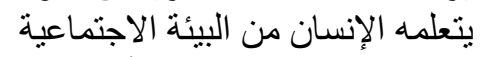

ألتي يعيش فيها، ومن الإنسان الهم رواد النظاعية النظرية باندورا

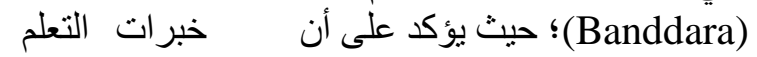

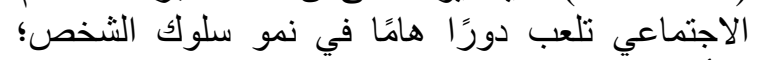

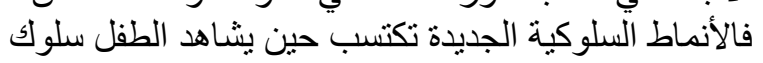

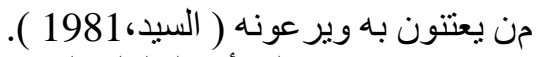

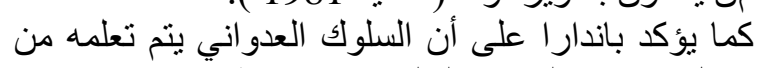

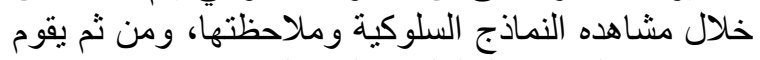

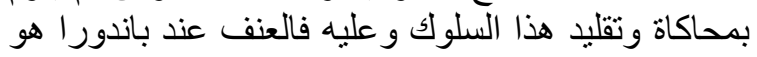

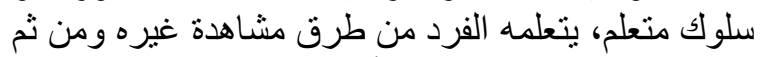

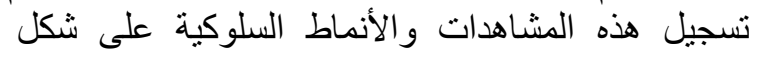

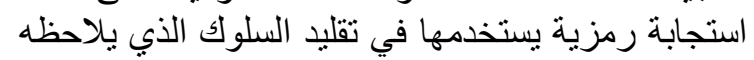

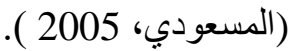

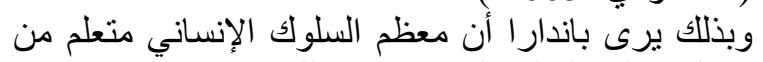

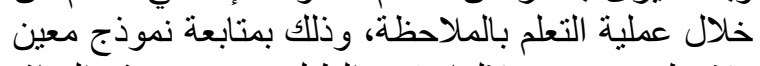

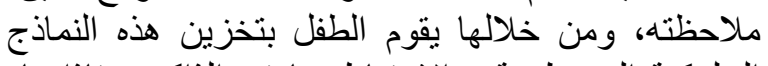

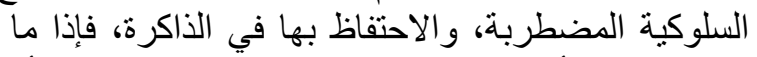

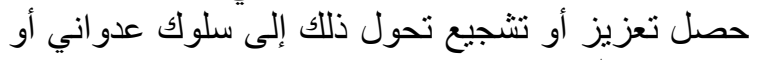

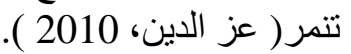
كما حدد باندارا ثلاثة معايير لتحديد سلوكيات التنمر

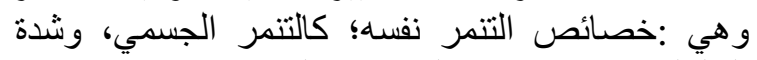

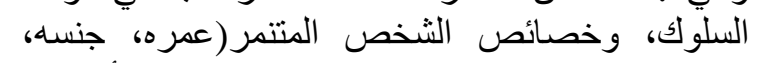

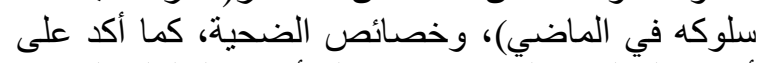
أهمية العمليات المعرفية في تعلم أنماط السلوك العدية العدواني الكي

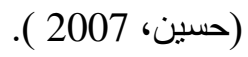

ومما سبق مفيسر الباحث سلوك التنمر وفقًا لهذه

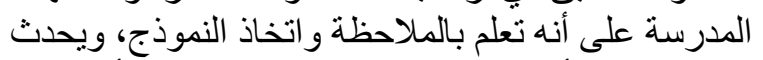

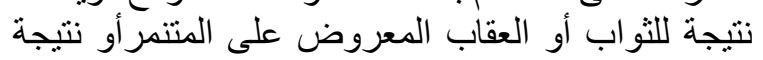

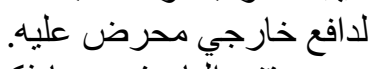

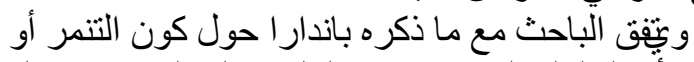

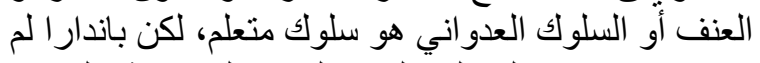

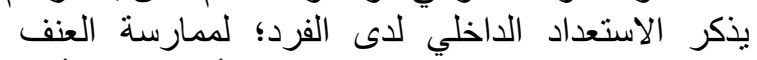

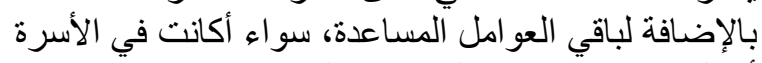
أو المجتمع بمؤسساته النظامية والمانية اللانظامية.

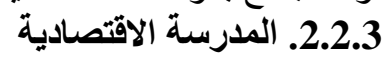

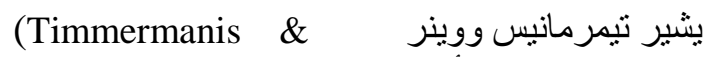
إلى أن كل التفاعلات و العلاقات Wiener, 2011)

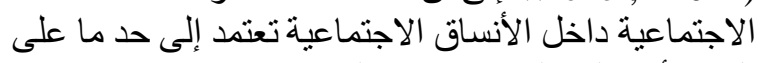

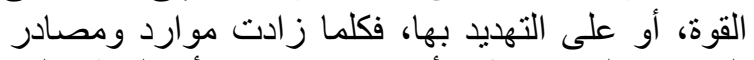

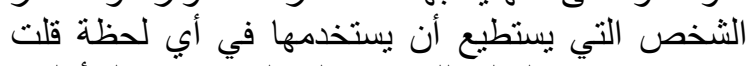
درجة ممارستّه الفعلية للعنف و ولى بلى العكس فُإنه يلجأ إلى فلى 
السن، و الجنس، و الحالة التعليمية، و عدد أفر اد

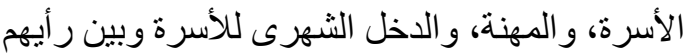

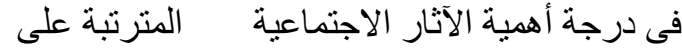

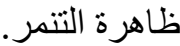

2 -توجد علاقة بين المتغير ات التالية للمبحوثين و هى:

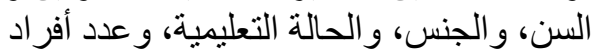

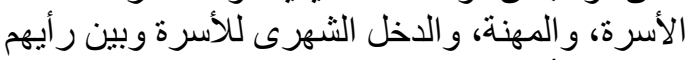

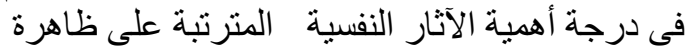
التنمر.

3- توجد علاقة بين المتغير ات التالية للمبحوثين وهى:

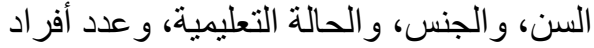

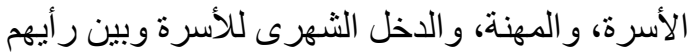

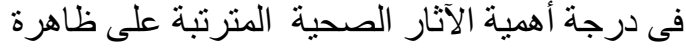
التنمر. و ولاختبار الفروض الثيار البحثية السابقة تم وضعها

$$
\text { فى صورتها الصفرية. }
$$

\section{5. الطريقة البحثية}

أجرى هذا البحث فى قرية بمها مركز العية العياط بمحافظة

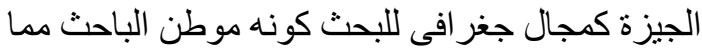

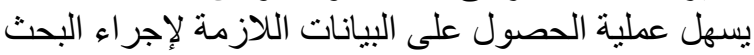

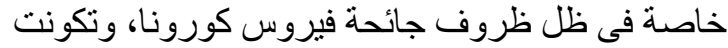

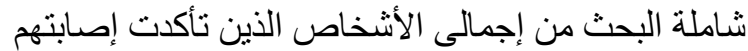

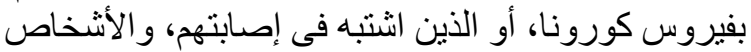

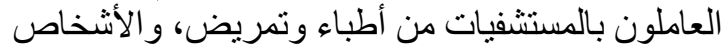

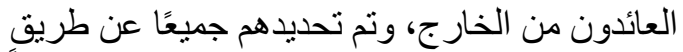

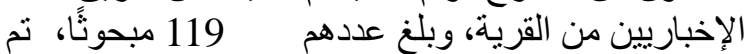
استبعاد 9 منهم والذين تم إجر اء الاختية عنبار المبدئى لاستمارة

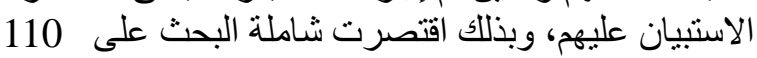
مبحوث، وقد اشتملت استمارة الاستبيان على أربعة أقسام

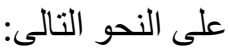

القسم الأول : واختص بيعض الخئل الخصائص الاجتماعية

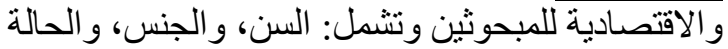

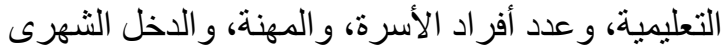

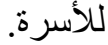

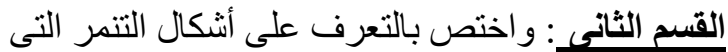

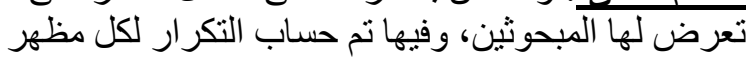

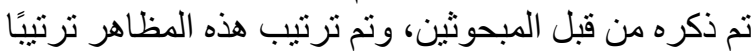

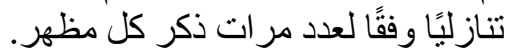

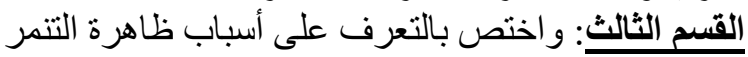

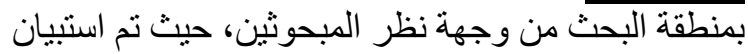

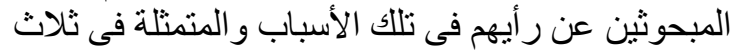

مجمو عات هى: الأسباب الاجتماعية، و الاقتصادية،

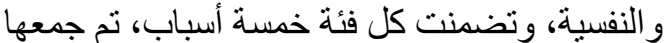
وحصر ها من الكتابات النظرية و البحوث العلمية، ونية وذلكي

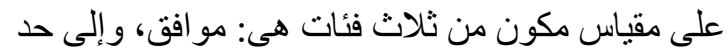
ما، و غير مو افق، و أعطيت الدرجات فئل الترتيب لتعبر عن رأى المبحوثين فى أسباب ظاهرة التتمر بمنطقة البحث. - مئر

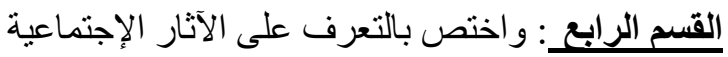
و النفسية والصحية لظاهرة التنمر بمنطقة البحث من وجهة الأنية

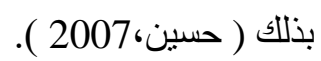

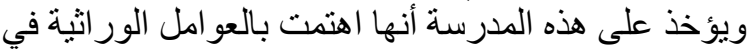

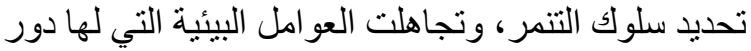
في تعديل سلوك التنمر، وكذلك التك العو امل النفسية التني تعتبر لتبر

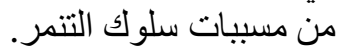

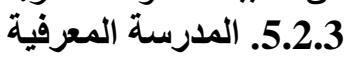

يعزى سلوك التنمر إلى فئل المبلى المتنمر في الفهم، وتدني

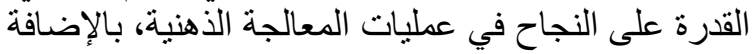

إلى ظهور مظاهر معرفية لديه منل ( حفنى ، 2005): 1 1-فنشل في المعالجة الذهنية. 2-فتشل في الانتباه و التركيز. 3-فنشل في النجاح و الإنجاز. 4-فنثل في الانهماك في المهي الإنة. 5-فثل في استخدام قدرات التعلم كالتحصيل و المذاكرة.

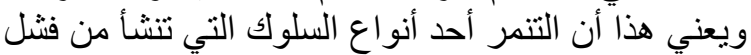

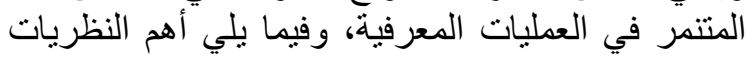

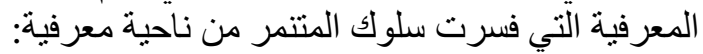

1-نظرية بيركويتز) (Berkiowitz)

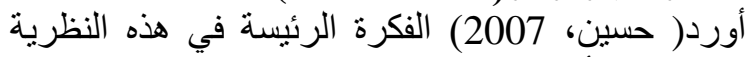

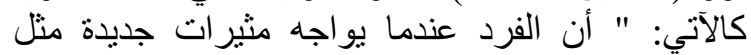

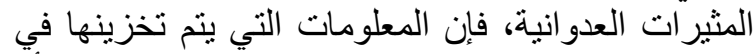

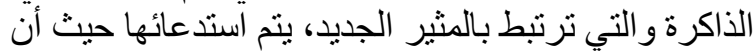

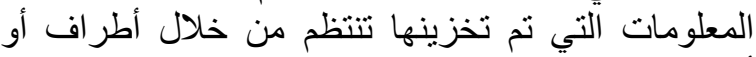

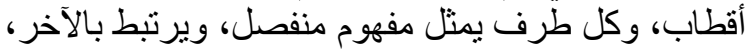

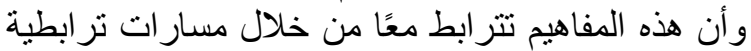

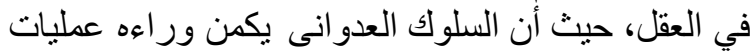
معرفية، وأن المكون المركزي في في العملئ العملية المعرفية

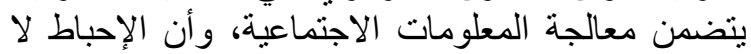

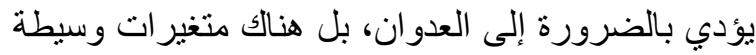
بين ألإحباط و العدوان، ويلعب الغضب كئب كتغير وسيط دورًا هامًا في ذلك.

2نظئة بياجيه (Piaget) أشار بياجيه (Piaget, 1973) إلى أن الفرد ومن خلال عمليتي التمثيل و المواءمة ليكون بنى إلى عقلية النية

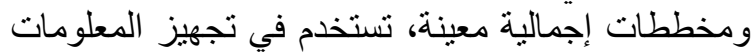
التي ترد إليه، وتزيد من قدرته في مواجهة فئهة مشكلاته

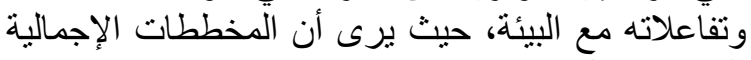
العامة هي التكوينات التينة

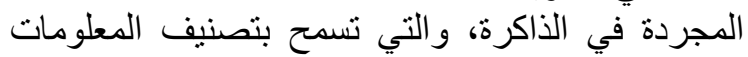

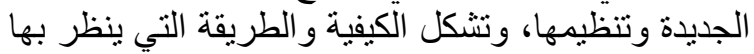

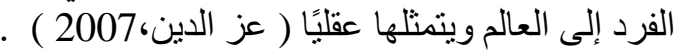

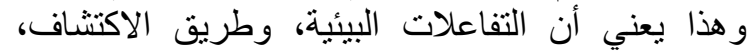

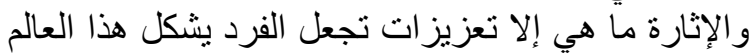

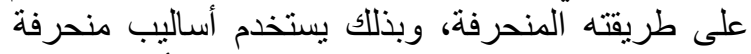
يرى فيها المخططات السوية التي يو اجه بها أنثكال التنمر في العالم الناتجة من زيادة تفاعلاته مع بيئته ومحيطه التهات

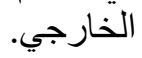

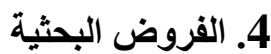

1 -توجد علاقة بين المتغير ات التالية للمبحوثين و هى: 
5 ما يزيد عن خمس المبحوثين (21.8\%) موظفين. 6 أكثر من نصف المبحوثين (56.3\%) اشثتبه فى إصابتهه

$$
\text { بفيروس كورونا. }
$$

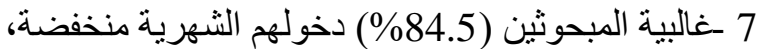

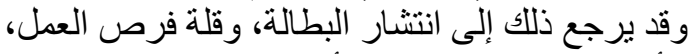

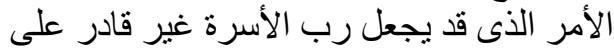
تحقيق ولو جزء بسيط من احتياجات أسرتها، والإنفاق

$$
\text { على تعليم أو لاده. }
$$

2.6. أشكال التنمر التى تعرض لهان التها المبحوثين

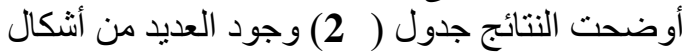

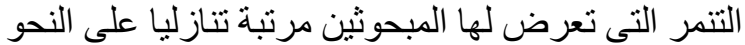

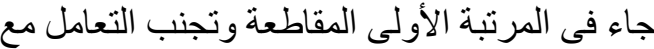

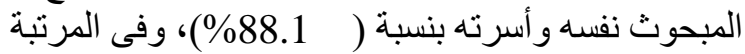

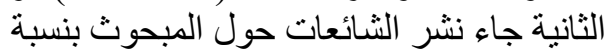

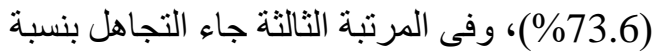

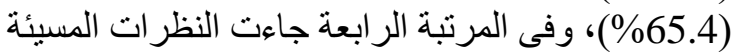

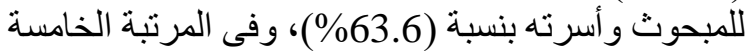

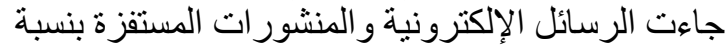

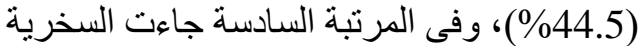

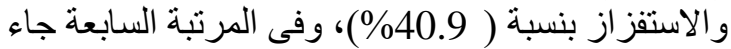

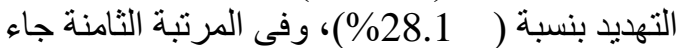
التعرض للشتائم بنسبة ( 10\%)، و وأخيرًا في المرتبة

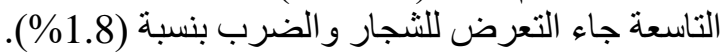

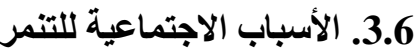
تحددت الأسباب الإجتماعية للتنمر فى خمسة أسباب، وجاءت استجابات المبحوثين عليها مرتبة ترتيبا لإنتيا تنازليا

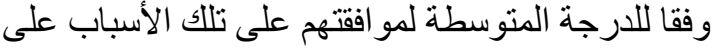

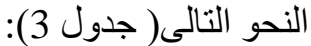

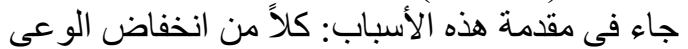

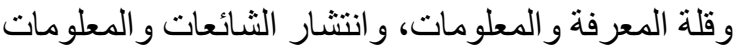

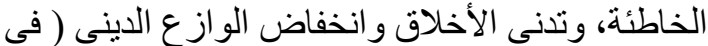

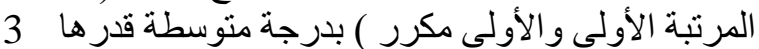

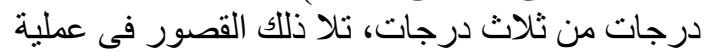

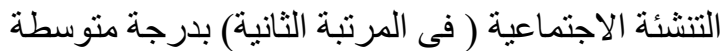

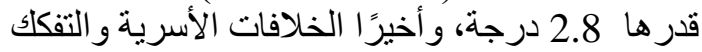
الأسرى ( فى المرتبة الثالثة ) بدرجة الخدات متوسطة قدر ها 2.2

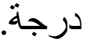
ولتحديد مستوى أهمية الأسباب الاجتماعية إجمالاً فقد

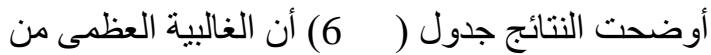
المبحوثين ( 99.1 \% \%) كان مستوى أهمية الأسباب

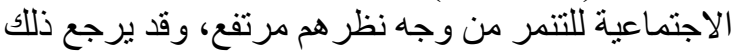

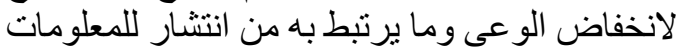

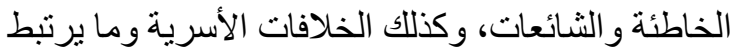

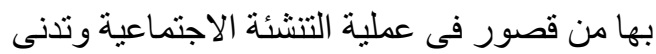
الأخلاق، الأمر الذى ينعكس في النهاية على تفاقم ظاهرة

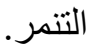

المبحوثين، حيث تم استيان المبحوثين عن ر أيهم فى الآثار

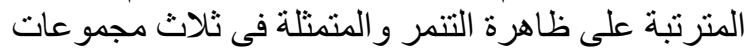

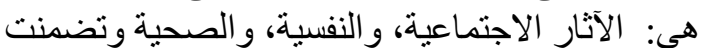

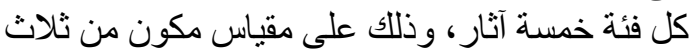

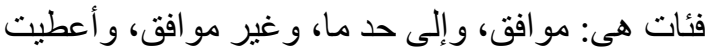

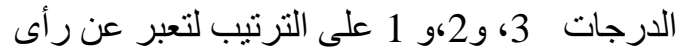
المبحوثين فى الآثار المترتبة على ظاهرة التنمر بمنطقة

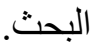

القسم الخامس: واختص بمقترحات المبحوثين للتغلب على التى

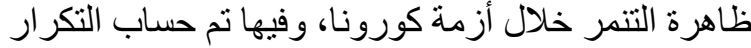

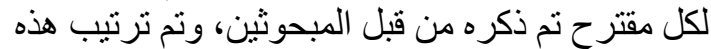

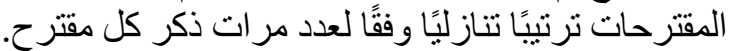

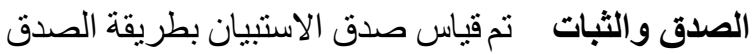

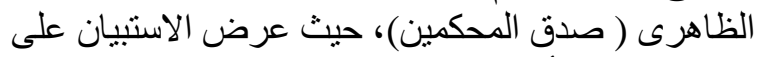

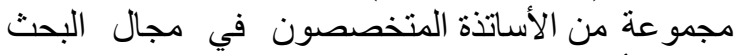

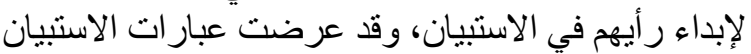

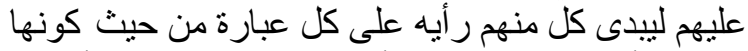

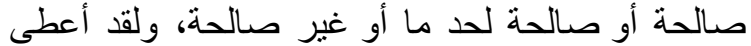

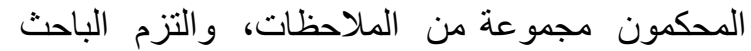

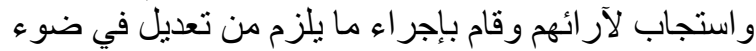

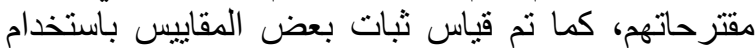
معامل ألفا كرونباخ، وقد كانت قيم ثيم معامل ألفا كرونباخ بـان

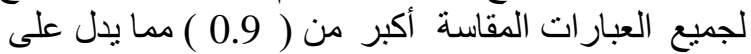
التبات العالى لأداة الاستبيان.

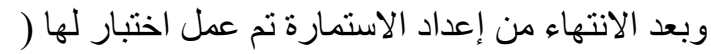

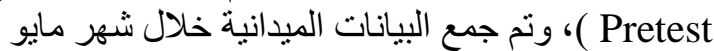

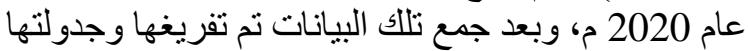

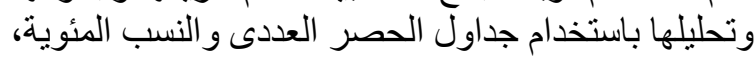
و التكر ارات، و الدرجة المتوسطة، ومعامل الارتباط التباط البسيط لبيرسون، ومعامل التطابق النسبى (مربع كاى ).

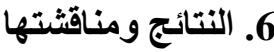

1.6. وصف عينة البحث

أوضحت النتائج ( جدول 1 1) أن المبحوثين يتوز عون التهون

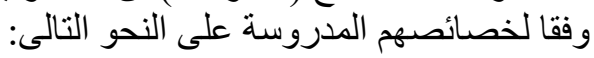

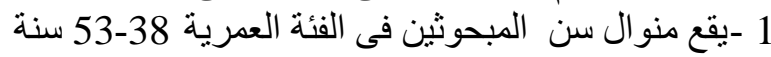

و بلغت نسبتهم (49 \% \%).

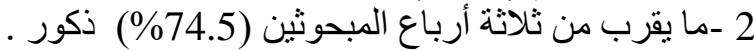

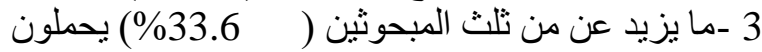

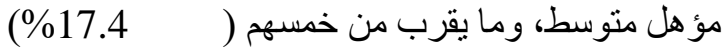
يحملون مؤ هل عالى. مئ.

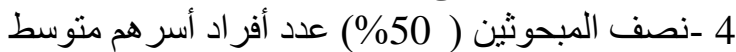

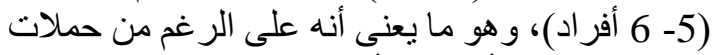

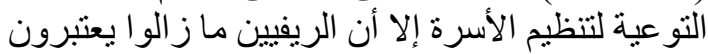

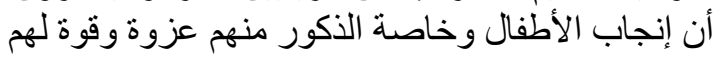

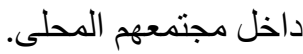


جدول (1): توزيع المبحوثين وفقًا لخصائصهم المدروسة.

\begin{tabular}{|c|c|c|c|c|c|}
\hline$\%$ & عدد & الخصائص & $\%$ & عدد & الخصائص \\
\hline & & 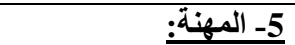 & & & 1ـــ السن: \\
\hline 4.5 & 5 & ربة منزل & 35.5 & 39 & 22- 22 37 سنة \\
\hline 16.4 & 18 & 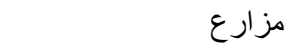 & 49 & 54 & -38- 3 - 53 سنة \\
\hline 15.5 & 17 & 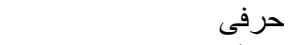 & 15.5 & 17 & 54- 66 سنة \\
\hline 21.8 & 24 & 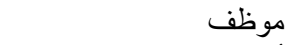 & & & \\
\hline 16.4 & 18 & أعمال حرة - مرة & & & \\
\hline 4.5 & 5 & طبيب & & & \\
\hline 20.9 & 23 & تمريض & & & \\
\hline \multirow[t]{2}{*}{100} & 110 & 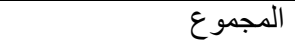 & 100 & 110 & المجموع \\
\hline & & 6- الحالة بالنسبة للتنمر: & & & 2 2- الجنس: \\
\hline 10 & 11 & إصـابة مؤكدة & 74.5 & 82 & \multirow{4}{*}{ أنثى } \\
\hline 56.3 & 62 & اثتباه إصـابة & 25.5 & 28 & \\
\hline 8.2 & 9 & عائد من الخارج & & & \\
\hline 25.5 & 28 & العمل بمستشفى & & & \\
\hline 100 & 110 & المجموع & 100 & 110 & المجموع \\
\hline \multirow{7}{*}{$\begin{array}{r}84.5 \\
13.6 \\
1.9\end{array}$} & \multirow{7}{*}{$\begin{array}{r}93 \\
15 \\
2\end{array}$} & 7ـ الدخل: & & & \multirow{2}{*}{ 3ـ الحالة التعليمية. } \\
\hline & & منخفض( 1000-3500) & 11.8 & 13 & \\
\hline & & متوسط( 4000-6500) & 13.6 & 15 & قر أ ويكتب \\
\hline & & عالى( (7000-10000) & 10 & 11 & إبتدائية \\
\hline & & & 13.6 & 15 & \multirow{2}{*}{ إعودادية هنو سط } \\
\hline & & & 33.6 & 37 & \\
\hline & & & 17.4 & 19 & مؤهل عالى \\
\hline \multirow[t]{6}{*}{100} & 110 & المجموع ل & 100 & 110 & 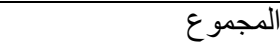 \\
\hline & & & & & 4- عدد أفر اد الأسرة: \\
\hline & & & 30 & 33 & أسرة صغيرة 3- 4 أفَر اد \\
\hline & & & 50 & 55 & أسرة متوسطة 5- 6 أفراد \\
\hline & & & 20 & 22 & أسرة كبيرة 7- 9 أفراد \\
\hline & & & 100 & 110 & 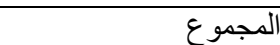 \\
\hline
\end{tabular}

جدول (2): توزيع المبحوثين وفقًا لأشكال التنمر التى تعرضوا لها .

\begin{tabular}{|c|c|c|c|c|}
\hline الترتيب & $\%$ & التكرارات & المقترحات & م \\
\hline 1 & 88.1 & 97 & المقاطعة وتجنب التعامل معىى ومع أسرتى & 1 \\
\hline 2 & 73.6 & 81 & نشر الثائعات حولى & 2 \\
\hline 3 & 65.4 & 72 & التجاهل & 3 \\
\hline 4 & 63.6 & 70 & النظرات المسيئة لى ولأسرتى & 4 \\
\hline 5 & 44.5 & 49 & الرسائل الاككترونية و المنشورات المستفزة & 5 \\
\hline 6 & 40.9 & 45 & السخرية والاستفزاز & 6 \\
\hline 7 & 28.1 & 31 & التهايد & 7 \\
\hline 8 & 10 & 11 & الثشتائم & 8 \\
\hline 9 & 1.8 & 2 & المشاجرة والضرب & 9 \\
\hline
\end{tabular}

\begin{tabular}{|c|c|c|c|c|c|c|c|c|c|c|c|}
\hline \multirow[b]{2}{*}{ التزتيب } & \multirow{2}{*}{ المرجح } & \multicolumn{2}{|c|}{ 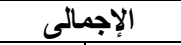 } & \multicolumn{2}{|c|}{ غير موافق } & \multicolumn{2}{|c|}{ 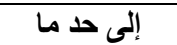 } & \multicolumn{2}{|c|}{ 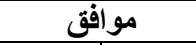 } & \multirow{2}{*}{ 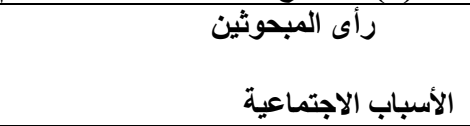 } & \\
\hline & & $\%$ & عدد & $\%$ & عداد & $\%$ & عدد & $\%$ & عدد & & \\
\hline 1 & 3 & 100 & 110 & - & - & - & - & 100 & 110 & انخفاض الوعى وقلة المعرفة والمعلومات & 1 \\
\hline 1 مكرر & 3 & 100 & 110 & - & - & - & - & 100 & 110 & انتثشار الثشائعات والمعلومات الخاطئة & 2 \\
\hline 3 & 2.2 & 100 & 110 & - & - & 75.5 & 83 & 24.5 & 27 & الخلافات الأسرية و التفكك الأسرى & 3 \\
\hline 2 & 2.8 & 100 & 110 & - & 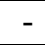 & 16.4 & 18 & 83.6 & 92 & القصور فى عملية التنشئة الاجتماعية & 4 \\
\hline 1 مكرر & 3 & 100 & 110 & 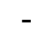 & 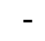 & - & - & 100 & 110 & تدنى الأخلاق وانخفاض الوازع اللينى & 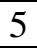 \\
\hline
\end{tabular}


جاء فى مقدمة هذه الآثار : كلاً من تأتثر علاقة المبحوث

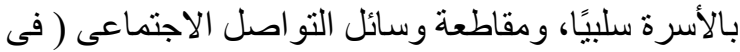

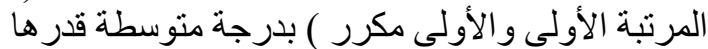

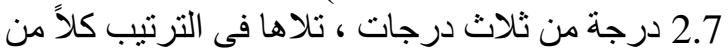

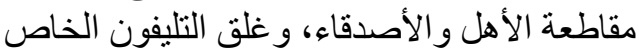

بالمبحوث ( فى المرتبة الثانية و الثانية مكرر) بدرجة الثانة

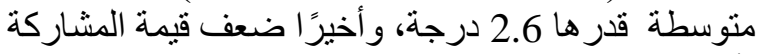

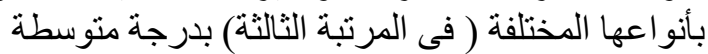

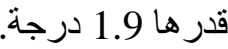
ولتحديد مدى مو افقة المبحوثين على الآثار الاجتماعية

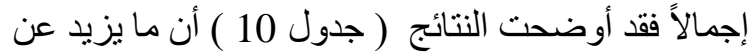

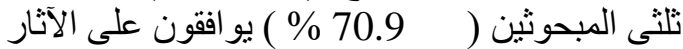

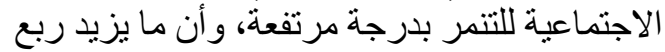

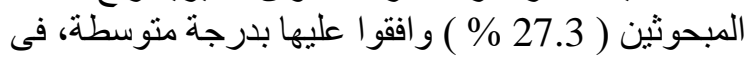

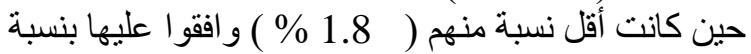

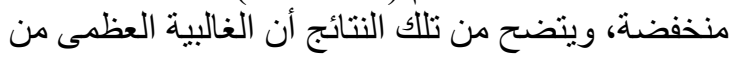

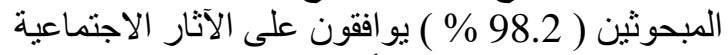

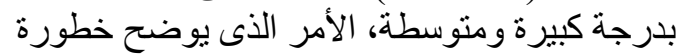
الظاهرة، وأن التنمر ينتج عنه العديد من الآثار الاجتماعية الأنية

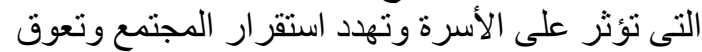

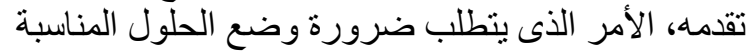

للتغلب على تللك الظاهرة للحد من آثار ها الاجتماعية. 7.6. الآثار النفسية المترتبة على التنمر من وجهة نظر التراعلية

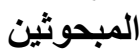

تحددت الآثار النفسية المترتبة على التتمر فى خمسة

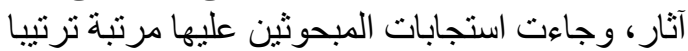

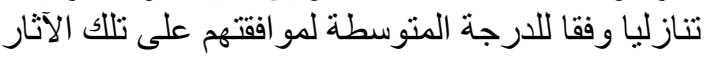

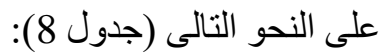

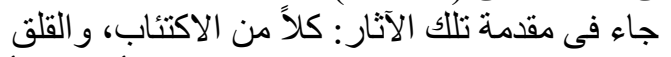

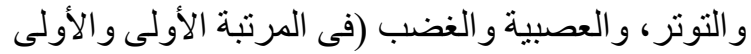

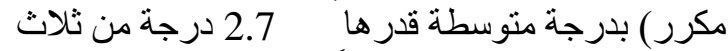

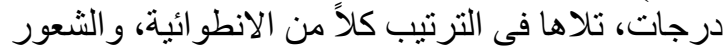

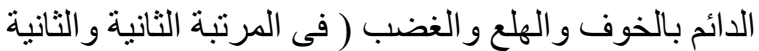

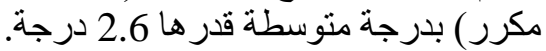
ولتحديد مدى مو افقة المبحوثين على التى الآثار النفسية

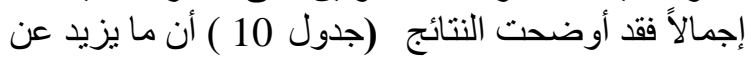

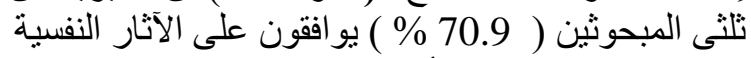

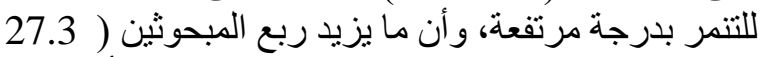

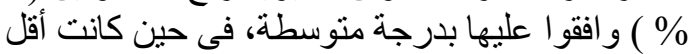

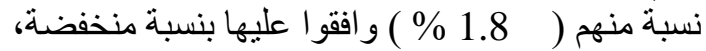

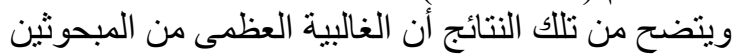

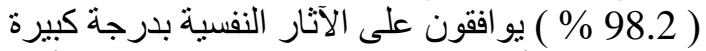

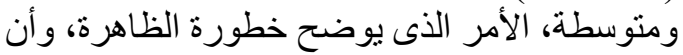

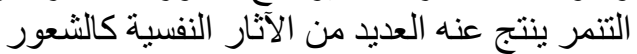

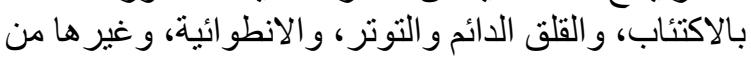

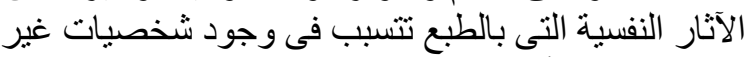

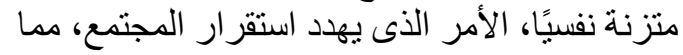

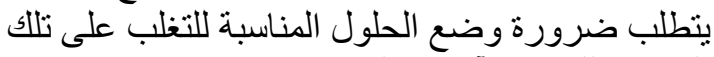
الظاهرة للحد من آثار ها النفسية.
4.6. الأسباب الاقتصادية للتنمر

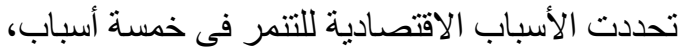
وجاءت استجابات المبحوثين عليها مرنبة ترتيبا تنازليا

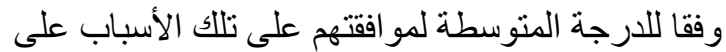

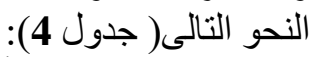

جاء فى مقدمة هذه الأسباب: الضغوط الضول المعيشية الصعبة

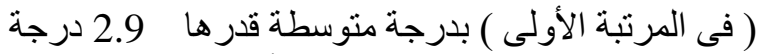
من ثلاث درجات، تلا ذللك الديون و الأقساط ( في المرنة

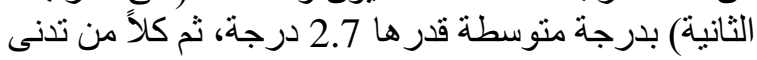

الدخول، و البطالة ( فى المرنبة الثالثة و الثالثة مكرر ) دانة

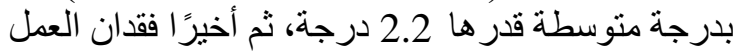

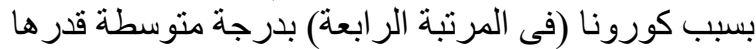

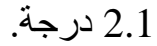

ولتحديد مستوى أهمية الأسباب الاقتصادية إجمالاً فقد

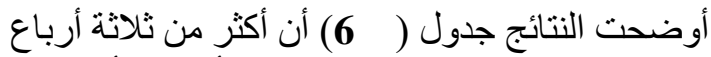

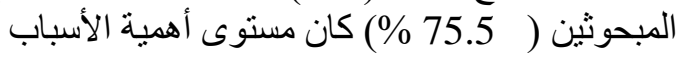

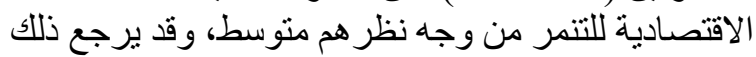

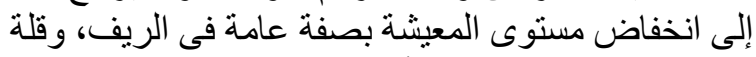

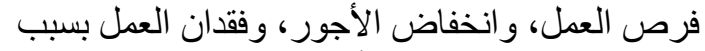

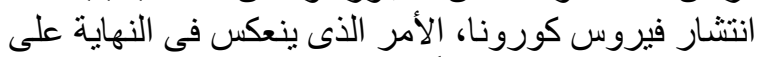
السلوك ويحدث به انحر انفًا متفاونًا.

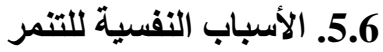

تحددت الأسباب النفسية للتنمر في خمسة أسباب،

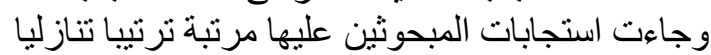

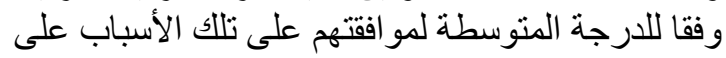

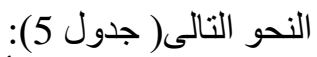
جاء فى مقدمة هذه الأسباب: الخوف الثَد الثديد من الإصـابة

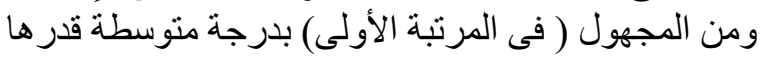

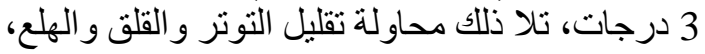

و الخوف من فقدان العمل ( فى المرتبة الثانية و الثانية

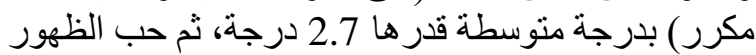

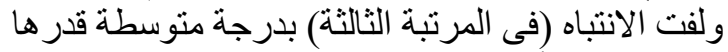

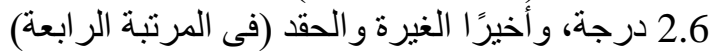
بدرجة متوسطة قدر ها 2 درجة الغيرة ولتحديد مستوى أهمية الأسباب الاقتصادية إجمالاً فقد

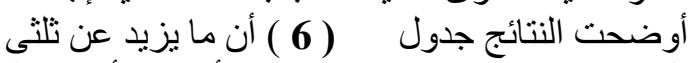
المبحوثين ( 69.1 \% \%) كان مستوى أهمية الأسباب النفسية

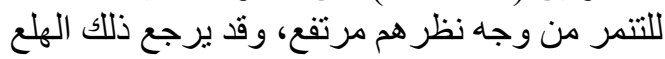

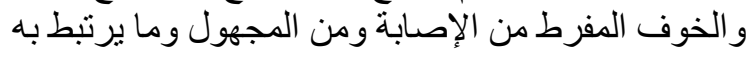

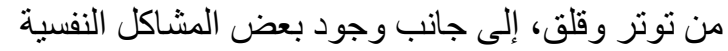

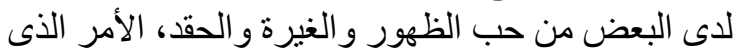

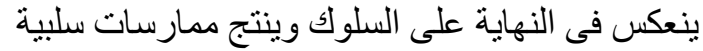
تجعل منه سلوك عدو الانى تجاه الآخئ الخرين.

6.6. الآثار الإجتماعية المترتبة على لألى التنمر من وجهة نظر المبحوثين الإجنما

تحددت الآثار الإجتماعية المترتبة على التنمر فى إنى

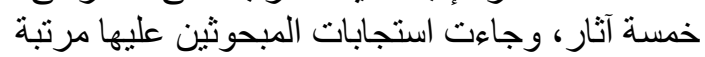

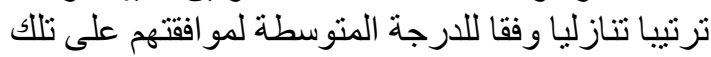
الآثار على النحو التالى (جدول 7) النيازئل 
جدول (4): توزيع المبحوثين وفقًا لرأيهم فى الأسباب الاقتصادية للتنمر .

\begin{tabular}{|c|c|c|c|c|c|c|c|c|c|c|c|}
\hline \multirow[b]{2}{*}{ الترتيب } & \multirow{2}{*}{ المرجح } & \multicolumn{2}{|c|}{ الإجمالى } & \multicolumn{2}{|c|}{ غير موافق } & \multicolumn{2}{|c|}{ إلى حذ ما } & \multicolumn{2}{|c|}{ موافق } & \multirow{2}{*}{ الأسباب الاقتصادية } & \multirow[b]{2}{*}{ 5 } \\
\hline & & $\%$ & عدد & $\%$ & عدد & $\%$ & عدد & $\%$ & عدد & & \\
\hline 4 & 2.1 & 100 & 110 & 4.5 & 5 & 75.5 & 83 & 20 & 22 & فقدان العمل بسبب كورونا & 1 \\
\hline 3 مكرر & 2.2 & 100 & 110 & - & - & 77.3 & 85 & 22.7 & 25 & البطالة بصفة عامة & 2 \\
\hline 3 & 2.2 & 100 & 110 & - & - & 80 & 88 & 20 & 22 & تلدى الاخول & 3 \\
\hline 1 & 2.9 & 100 & 110 & - & - & 4.5 & 5 & 95.5 & 105 & الضغوط المعيشية الصعبة & 4 \\
\hline 2 & 2.7 & 100 & 110 & - & - & 23.6 & 26 & 76.4 & 84 & الديون والأقساط & 5 \\
\hline
\end{tabular}

جدول (5): توزيع المبحوثين وفقًا لرأيهم فى الأسباب النفسية للتنمر.

\begin{tabular}{|c|c|c|c|c|c|c|c|c|c|c|c|}
\hline \multirow[b]{2}{*}{ الترتيب } & \multirow{2}{*}{ المرجح } & \multicolumn{2}{|c|}{ الإجمالى } & \multicolumn{2}{|c|}{ مو أفير } & \multicolumn{2}{|c|}{ إلى حـا } & \multicolumn{2}{|c|}{ موافق } & \multirow[t]{2}{*}{ رأى المبحوثين } & \multirow[b]{2}{*}{ s } \\
\hline & & $\%$ & عدد & $\%$ & عدد & $\%$ & عدد & $\%$ & عدد & & \\
\hline 1 & 3 & 100 & 110 & - & - & - & - & 100 & 110 & الخوف الثُديد من الإصابة ومن المجهول & 1 \\
\hline 3 & 2.6 & 100 & 110 & - & - & 29.1 & 32 & 69.1 & 76 & حب الظهور ولفت الانتباه & 2 \\
\hline 2 & 2.7 & 100 & 110 & - & - & 20.9 & 23 & 79.1 & 87 & محاولة لتقليل التوتر والقلق والهلع & 3 \\
\hline (2 - 2 2 مكرر & 2.7 & 100 & 110 & - & - & 20.9 & 23 & 79.1 & 87 & الخوف من فقدان العمل & 4 \\
\hline 4 & 2 & 100 & 110 & - & - & 34.5 & 38 & 65.5 & 72 & الغيرة والحقد & 5 \\
\hline
\end{tabular}

جدول (6): توزيع المبحوثين وفقًا لمستوى أهمية الأسباب الاجتماعية، والاقتصادية، والنفسية للتنمر إجمالاً.

\begin{tabular}{|c|c|c|c|c|c|c|c|}
\hline \multicolumn{2}{|c|}{ الأسباب النفسية } & \multicolumn{2}{|c|}{ الأسباب الاقتصادية } & \multicolumn{2}{|c|}{ الأسباب الاجتماعية } & \multirow{2}{*}{ مستوى الأهمية الأسباب } & \multirow[b]{2}{*}{ 5 } \\
\hline$\%$ & عدد & $\%$ & عدد & $\%$ & عدد & & \\
\hline 20.9 & 23 & 4.5 & 5 & 0.9 & 1 & منخفض & 1 \\
\hline 10 & 11 & 75.5 & 83 & - & - & متوسط & 2 \\
\hline 69.1 & 76 & 20 & 22 & 99.1 & 109 & مرتفع & 3 \\
\hline
\end{tabular}

جدول (7) : تو زيع المبحوثين وفقًا لرأيهم فى آثار التنمر الاجتماعية.

\begin{tabular}{|c|c|c|c|c|c|c|c|c|c|c|c|}
\hline \multirow[b]{2}{*}{ الترتيب } & \multirow{2}{*}{ المرجح } & \multicolumn{2}{|c|}{ الإجمالى } & \multicolumn{2}{|c|}{ غير موافق } & \multicolumn{2}{|c|}{ إلى حد ما } & \multicolumn{2}{|c|}{ موافق } & \multirow{2}{*}{ 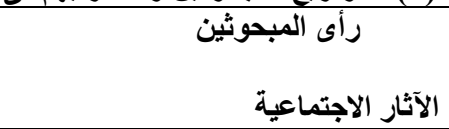 } & \multirow[b]{2}{*}{ ? } \\
\hline & & $\%$ & عدد & $\%$ & عدد & $\%$ & عدد & $\%$ & عدد & & \\
\hline 1 & 2.7 & 100 & 110 & 1.8 & 2 & 27.3 & 30 & 70.9 & 78 & علاقتى بأسرتى تأثرت سلبًا & 1 \\
\hline 2 & 2.6 & 100 & 110 & 1.8 & 2 & 31.8 & 35 & 66.4 & 73 & مقاطعة الأهل والأصدقاء & 2 \\
\hline 2 مكرر 2 & 2.6 & 100 & 110 & 1.8 & 2 & 31.8 & 35 & 66.4 & 73 & غلق التليفون الخاص بي & 3 \\
\hline 1 مكرر 1 & 2.7 & 100 & 110 & - & - & 29.1 & 32 & 70.9 & 78 & مقاطعة وسائل التواصل الاجتماعى & 4 \\
\hline 3 & 1.9 & 100 & 110 & 1.8 & 2 & 88.2 & 97 & 10 & 11 & ضعف قيمة المشاركة بأنواعها المختلفة & 5 \\
\hline
\end{tabular}

جدول (8): توزيع المبحوثين وفقًا لرأيهم فى آثار التنمر النفسية.

\begin{tabular}{|c|c|c|c|c|c|c|c|c|c|c|c|}
\hline \multirow[b]{2}{*}{ الترتيب } & \multirow{2}{*}{ المرجح } & \multicolumn{2}{|c|}{ الإجمالى } & \multicolumn{2}{|c|}{ غير موافق } & \multicolumn{2}{|c|}{ إلى حلى ما } & \multicolumn{2}{|c|}{ موافق } & \multirow{2}{*}{$\begin{array}{l}\text { الآثار النفسية المبحوثين } \\
\text { النين }\end{array}$} & \multirow[b]{2}{*}{ r } \\
\hline & & $\%$ & عدد & $\%$ & عدد & $\%$ & عدد & $\%$ & عدد & & \\
\hline 1 & 2.7 & 100 & 110 & 1.8 & 2 & 27.3 & 30 & 70.9 & 78 & | الاكتئاب & 1 \\
\hline 2 & 2.6 & 100 & 110 & 1.8 & 2 & 31.8 & 35 & 66.4 & 3 & الانظو ائية & 2 \\
\hline 1 مكرر 1 مكرر & 2.7 & 100 & 110 & - & - & 23.6 & 26 & 76.4 & 84 & القلق والتوتر & 3 \\
\hline 1 1 مكرر 1 & 2.7 & 100 & 110 & 1.8 & 2 & 27.3 & 30 & 70.9 & 78 & العصبية و الغضب & 4 \\
\hline 2 2 مكرر & 2.6 & 100 & 110 & 4.5 & 5 & 24.5 & 27 & 70.9 & 78 & الثعور الدائم بالخوف & 5 \\
\hline
\end{tabular}


ينعكس على العلاقات الأسرية وانحسار الخلافات داخل

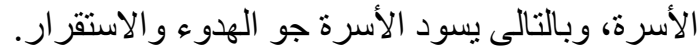
- وجود علاقة معنوية عند مستوى 0.01 بين جنس الأنس المبحوثين، وبين رأيهم فى درجة أهية أهمية الآثار

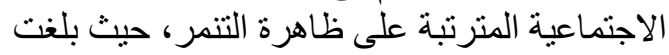

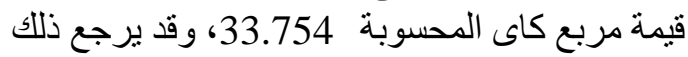

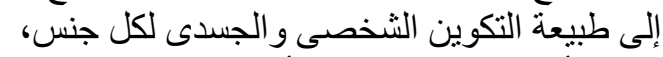

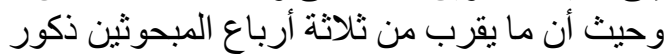

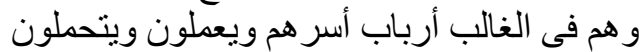

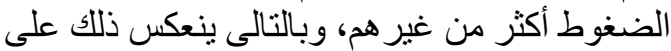

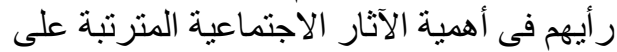

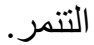

- موجود علاقة معنوية عند مستوى 0.010. المبحوثين، وبين رأيهم فى درجة أهنية أهمية الآثار

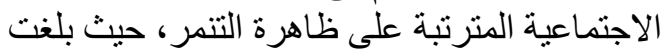

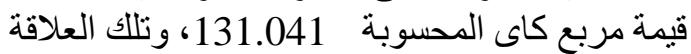

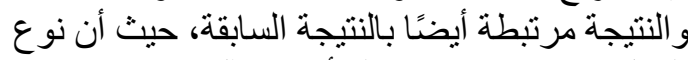
العمل نفسه يؤثر فى إدر الك أهمية الآثار الاجتماعية التية المترنبة على التنمر. - عدم وجود علاقة معنوية بين باقى المتغير ات المستقلة

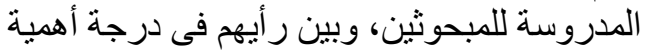
الآثار الاجتماعية المترتبة على ظلى لاهرة التنمر.

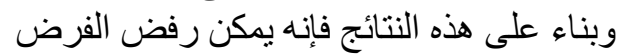

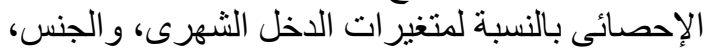

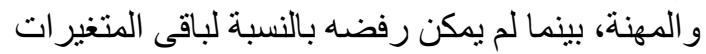

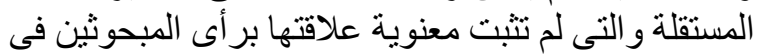

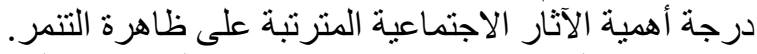

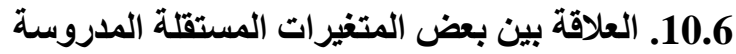
للمبحوثين وبين رأيهم فى درجة المئن أهمية الآثار النفسية المترتبة على ظاهرة التنمر فين الهر بناءً على الهذف السادس، و الفرض الفئ على الإحصائى الثانى

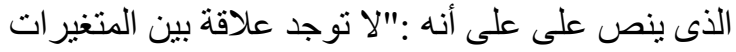

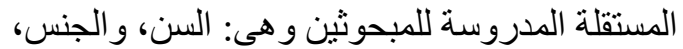

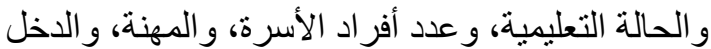

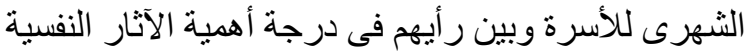

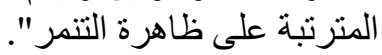

و لاختبار صحة هذا الفرض تمرة استخدام كل من :معامل

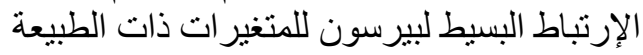

المتصلة، ومربع كاى للمتغير ات المنير الرتبية والإسمية، والطية وجاءت

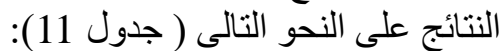
ـوجود علاقة ارتباطية عكسية عند مستوى 0.010.

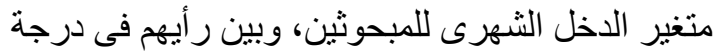

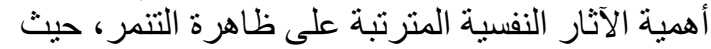

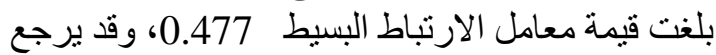

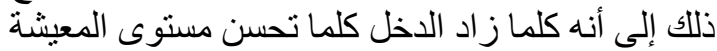

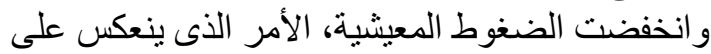

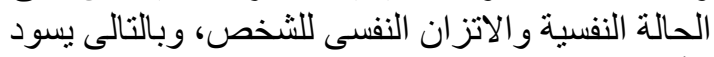
الأسرة جو الهذوء و الاستقرار.

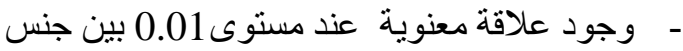
المبحوثين، وبين رأيهم فى درجة أهمية الآثار
8.6. الآثار الصحية المترتبة على التنمر من وجهة نظر

$$
\text { المبحوثين }
$$

تحددت الآثار الصحية المترتبة على التنمر فى

خمسة آثار ، وجاءت استجابات المبحوثين عليها مرنبة التبات ترتيبا تنازليا وفقا للارجة المتوسطة لمو افقته على تلكي

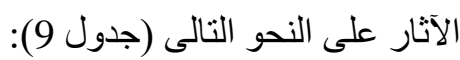

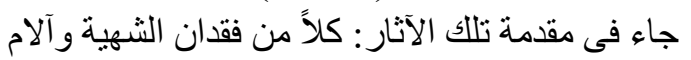

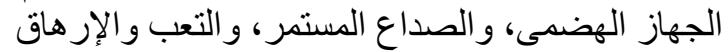

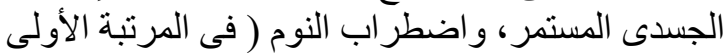

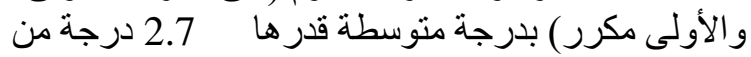

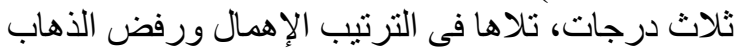

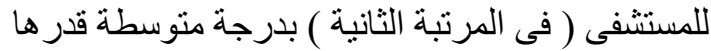
2.5 2.5

ولتحديد مدى مو اققة المبحوثين على الآثار الصحية

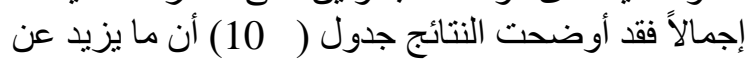

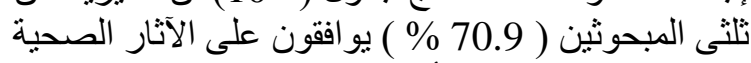

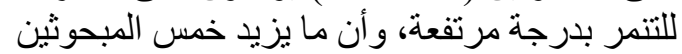

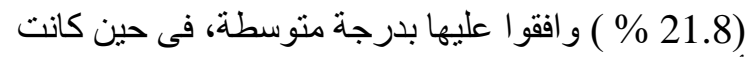

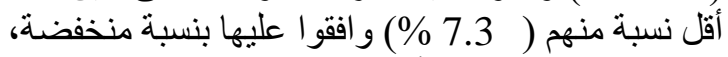
ويتضح من تلاك النتائج أن الغالبية العظمى من المبحوثين

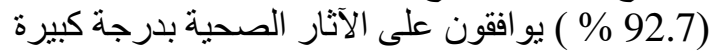

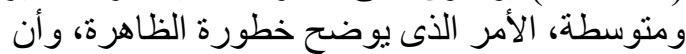

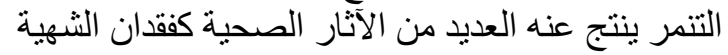

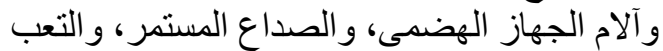

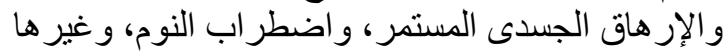

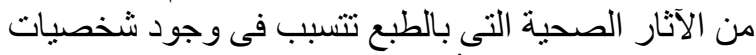

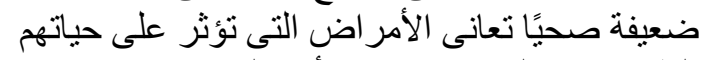

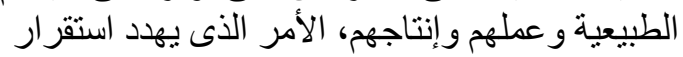

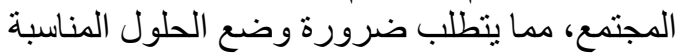
للتغلب على تلكالك الظاهرة للحد من آثنار ها الصحية.

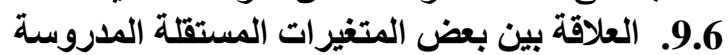

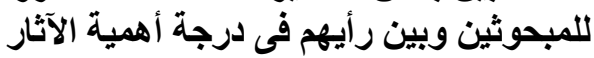

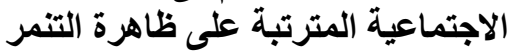

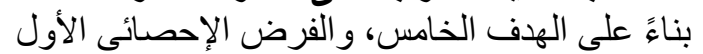

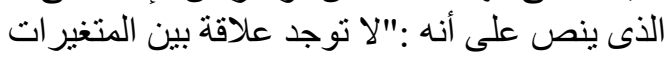

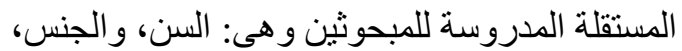
و الحالة التعليمية، و عدد أفر اد الأسرة، و المهنة الدرنة، و الدخل

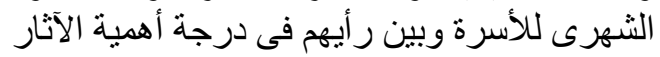

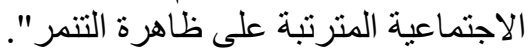

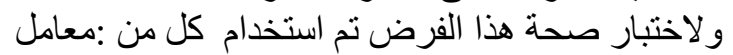

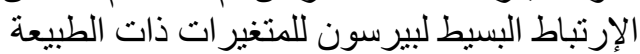

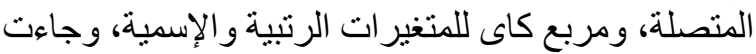

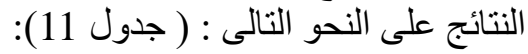
- وجود علاقة ارتباطية عكسية عند مستوى 0.010.

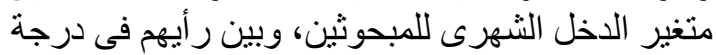

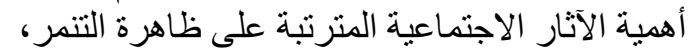

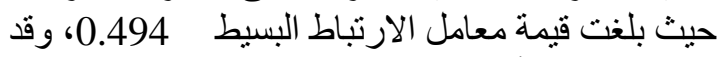

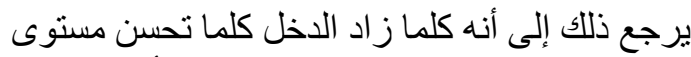

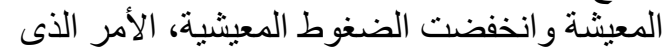


جدول (9): توزيع المبحوثين وفقًا لرأيهم فى آثار التنمر الصحية .

\begin{tabular}{|c|c|c|c|c|c|c|c|c|c|c|c|}
\hline \multirow{2}{*}{ الترتيب } & \multirow{2}{*}{ المرجح } & \multicolumn{2}{|c|}{ الإجمالى } & \multicolumn{2}{|c|}{ مو غير } & \multicolumn{2}{|c|}{ إلى حا } & \multicolumn{2}{|c|}{ 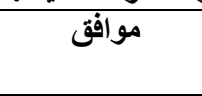 } & \multirow{2}{*}{ الآثار الصحية } & \multirow{2}{*}{ b } \\
\hline & & $\%$ & عدد & $\%$ & عدد & $\%$ & عدد & $\%$ & عدد & & \\
\hline 2 & 2.5 & 100 & 110 & 11.8 & 13 & 21.8 & 24 & 66.4 & 73 & الإهمال ورفض الذهاب للمستثفى & 1 \\
\hline 1 & 2.7 & 100 & 110 & 1.8 & 2 & 27.3 & 30 & 70.9 & 78 & فقدان الثهية وآلام الجهاز الهضمى & 2 \\
\hline 1 (1 مكرر & 2.7 & 100 & 110 & - & - & 29.1 & 32 & 70.9 & 78 & الصداع المستمر & 3 \\
\hline 1 (1 مكرر & 2.7 & 100 & 110 & - & - & 29.1 & 32 & 70.9 & 78 & التعب والإرهاق الجسدى المستمر & 4 \\
\hline 1 1 1 مكرر & 2.7 & 100 & 110 & 1.8 & 2 & 27.3 & 30 & 70.9 & 78 & قلّة النوم أو النوم بكثرة & 5 \\
\hline
\end{tabular}

جدول ( 10): توزيع المبحوثين وفقًا لموافقتهم على الآثار الاجتماعية والنفسية والصحية المترتبة على التنمر إجمالاً.

\begin{tabular}{|c|c|c|c|c|c|c|c|}
\hline \multicolumn{2}{|c|}{ الآثار الصحية } & \multicolumn{2}{|c|}{ الآثار النفسية } & \multicolumn{2}{|c|}{ الآثار الاجتماعية } & \multirow{2}{*}{ مستوى الموافقة } & \multirow[b]{2}{*}{ ? } \\
\hline$\%$ & عدد & $\%$ & عدد & $\%$ & عدد & & \\
\hline 7.3 & 8 & 1.8 & 2 & 1.8 & 2 & منخفض & 1 \\
\hline 21.8 & 24 & 27.3 & 30 & 27.3 & 30 & متوسط & 2 \\
\hline 70.9 & 78 & 70.9 & 78 & 70.9 & 78 & مرتفع & 3 \\
\hline
\end{tabular}

جدول ( 11): قيم معامل الارتباط البسيط ومريع كاى للعلاقة بين المتغيرات المستقلة المدروسة للمبحوثين وبين رأيهم فى درجة أهمية الآثار الاجتماعية، والنفسية، والصحية المترتبة على التنمر.

\begin{tabular}{|c|c|c|c|}
\hline \multicolumn{3}{|c|}{ قيم معامل الارتباط البسيط } & \multirow{2}{*}{ المتغيرات المستقلة المدروسة } \\
\hline الآثار الصحية & الآثار النفسية & الآثار الاجتماعية & \\
\hline 0.099 & 0.089 & 0.060 & السن \\
\hline 0.128 & 0.108 & 0.076 & عدد أفراد الأسرة \\
\hline$* * 0.521-$ & $* * 0.477-$ & $* * 0.494-$ & الاخل الشهرى للأسرة \\
\hline \multicolumn{4}{|c|}{ قيم مربع كاى } \\
\hline$* * 34.033$ & $* * 37.326$ & $* * 33.754$ & الجنس \\
\hline$* * 43.221$ & 30.598 & 30.191 & الحالة التعليمية \\
\hline$* * 174.734$ & $* * 149.891$ & $* * 131.041$ & المهنة \\
\hline
\end{tabular}

0.01 ** معنوية عند مستوى *

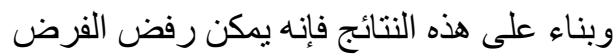

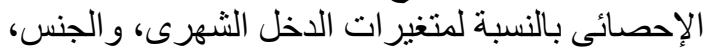

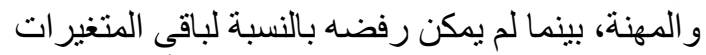

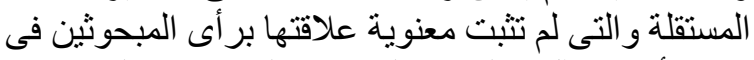

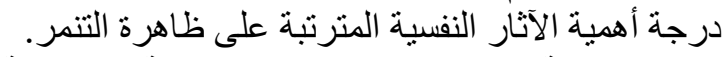

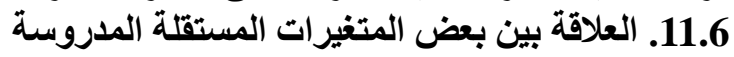

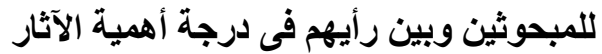
الصحية المترتبة على ظاهرة التنمر

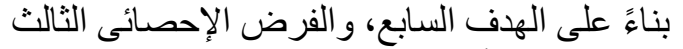

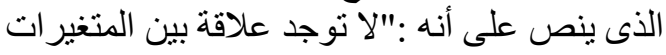

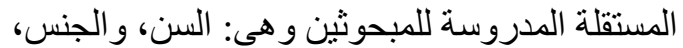
و الحالة التعليمية، و عدد أفر اد الأسرة، و المهنة، ولهن والدخل الثهرى للأسرة وبين ر أيهم فى درجة الهرة أهمبة الآثار الصحية المترتبة على ظاهرة التنمر ".

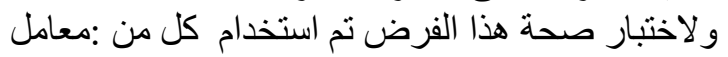
الإرتباط البسيط لبيرسون للمتغير ات ذات الطبيعة مل مل
النفسية المترتبة على ظاهرة التتمر، حيث بلغت قيمة

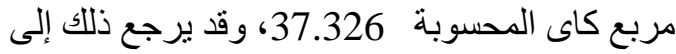

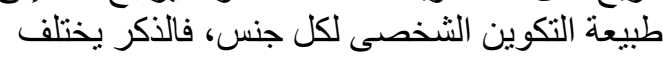
عن الأنتى فى إدر اكه ور أيه في أهمية الآثار النفسية المترتبة على التنمر.

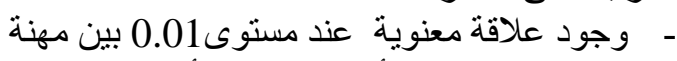

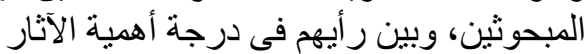

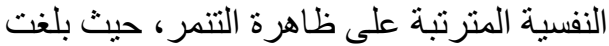

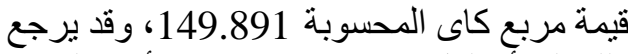

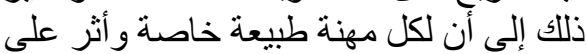
شخصية الفرد، وبالتالى تؤثر في إدر اكه لأهمية ألأية الآثار النفسية المترتبة على التنمر.

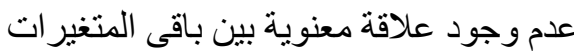

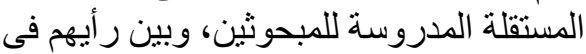
درجة أهمية الآثار النفسية المترنبة على ظاهرة التنمر. 
لباقى المتغير ات المستقلة والتى لم تثبت معنوية علاقتها بر أى المبحوثين فى درجة أهمية الآثار الصحية المترتبة الصية على ظاهرة التنمر.

12.6. مقترحات المبحوثين للتظلب على ظاهرة التنمر خلال جائحة كورونات المونيا

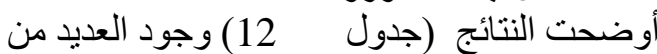

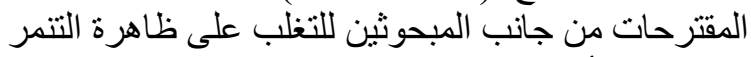

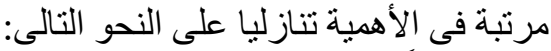
جاء كلاً من تفعيل دور الإعلام في رفي رفع الوعى ونى ونشر

المعلومات الصحيحة باستمرار حول فيروس كوري كورنا،

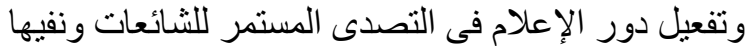

وتصحيحها ( فى المرتبة الأولى والأولى الألى مكرر ) بنسبة

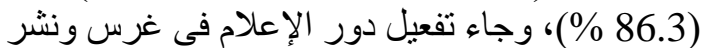

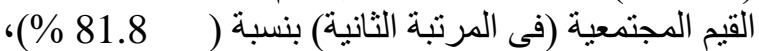

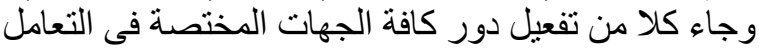

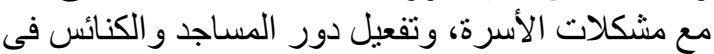

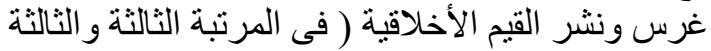

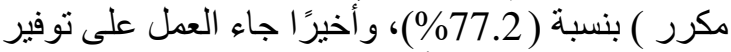

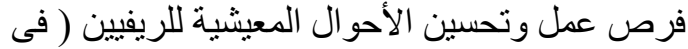
المرتبة الرابعة ) بنسبة (72.7\%).
المتصلة، ومربع كاى للمتغير ات الرتبية و الإسمية، وجاءت

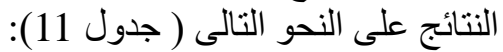

وجود علاقة ارتباطية عكسية عند مستوى 0.01

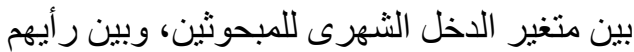

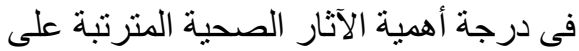

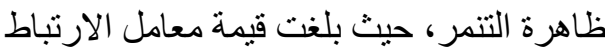

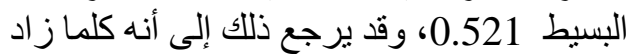

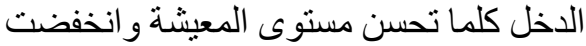

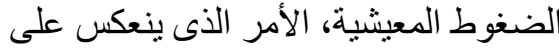
الحالة الصحية للشخص.

وجود علاقة معنوية عند مستوى 0.01 بين جنس الأنار

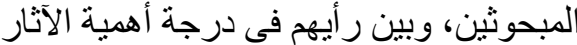

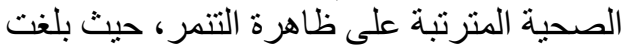

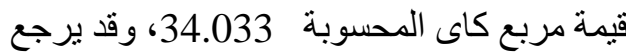
ذللك إلى طبيعة التكوين الشخصى لكل لكل جنس،

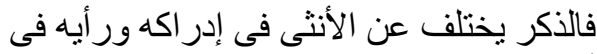
أهمية الآثار الصحية المترنبة على التئ التنمر.

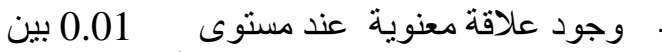

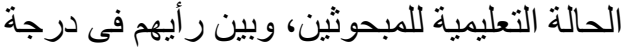
أهمية الآثار الصحية المترنبة على ظاهية لهين

\begin{tabular}{|c|c|c|c|c|}
\hline الترتيب & $\%$ & التكرارات & 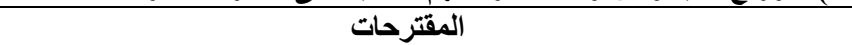 & P \\
\hline 1 & 86.3 & 95 & تفيروس كور الإعلام فى رفع الوعى ونثر المعلومات الصحيحة باستمرار حول & 1 \\
\hline 1 مكرر & 86.3 & 95 & تفعيل دور الإعلام في التصدى المستمر للثائعات ونفيها وتصحيحها & \\
\hline 2 & 81.8 & 90 & تفعيل دور الإعلام فى غرس ونثر القيم المجتمعية & 2 \\
\hline 3 & 77.2 & 85 & تفعيل دور كافة الجهات المختصة فى التعامل مع مشكلات الأسرة & 3 \\
\hline 3 & 77.2 & 85 & تفعيل دور المساجد والكنائس فى غرس ونشر الققيم الأخلاقية & 4 \\
\hline 4 & 72.7 & 80 & العمل على توفير فرص عمل وتحسين الأحوال المعيشية للريفيين & 5 \\
\hline
\end{tabular}

\section{توصيات البحث}

1 - تفعيل دور الإعلام فى رفع الو عى ونشر

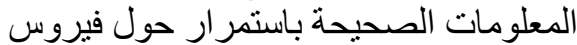

كورونا، و التصدى المستمر للثائعات ونفيها فئهيا وتصحيحها، وتفعيل دوره فى غرس قليم لإني الإخاء و و المحبة و التعاون.

2 ـ تفعيل دور المساجد و الكنائس في مو اجهة ظاهرة

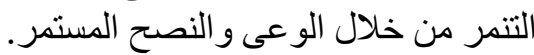

3 - ضرورة زيادة التعاون و التنسيق بين كافة التئ

الجهات سواء الإعلام أو المدارس أو المؤسئسات

الدينية أو الجمعيات الأهلية أو مر اكز الثباب الثباب الثبات

و غير ها من المؤسسات لمحاربة ظاهرة التهات التنمر

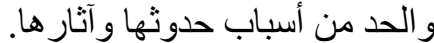
4 - على الباحثين و الأكاديميين و المنظمات الحقو الحقاتية

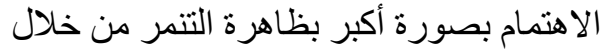

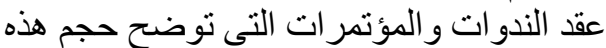
الظاهرة و أسبابها ومدى خطورتهرات التها على المجتمع هذه

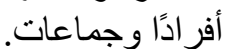

التنمر ، حيث بلغت قيمة مربع كاى المحسوبة

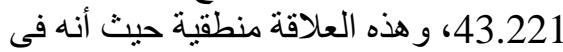
الغالب كلما كان الثخص أكثر تعليمًا كلما كان أكثر إدر اكًا للآثار الصحية المترنبة على ظاهرة التنمر.

وجود علاقة معنوية عند مستوى0.01 بين مهنة المبحوثين، وبين رأيهم فى درجة أهية أهية الآثار

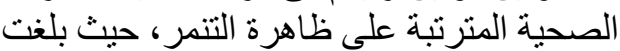

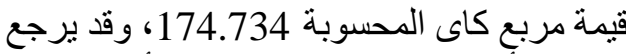

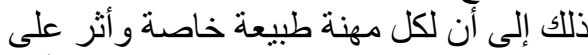
شخصية الفرد، وبالتالى تؤثر فى إدر اكه لألهية الهية الآثار الصحية المترتبة على التنمر.

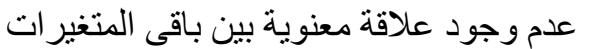

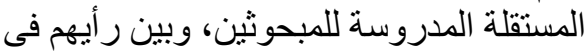
درجة أهمية الآثار الصحية المترتبة على ظاهرة التنمر.

وبناء على هذه النتائج فإنه يمكن رفض الفرض الفري

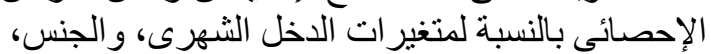
و الحالة التعليمية، و المهنة، بينما لم يمكن رفضينه بالنسبة النية 
عز الدين، خالد :( 2010 ) . السلوك العدواني عند

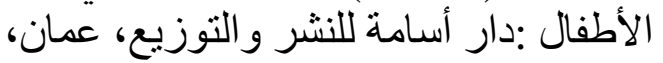

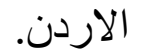

Banks R. (1997). Bullying in Schools, ERIC: ED407154,

http://www.vtaide.com/png/ERIC/Bullyin g Bullying-in-Schools .htm.

Barton E. A. (2003). Tips and strategies for school leaders and classroom teachers, Skylight Professional Development-USA.

https://arabic.sputniknews.com/arab_world/2020 04151045182271

Berkowitz, L. (1990). On the formation and regulation of anger and aggression: A cognitive-neoassociationistic

analysis. American Psychologist, 45(4), 494-503.

Rigby K. and Philip T. T. (1991). Bullying among Australian school children: Reported behavior and attitudes towards victims, J. soc. Psychol., 131: 615-727.

Litwiller B. J. and Brausch A.M. (2013). Cyber Bullying and Physical Bullying in Adolescent Suicide: The role of violent behavior and substance use, J. Youth and Adolescence, 24 (5): 675-684.

Nasel T.R. (2001). Bullying Behaviors among US Youth Prevalence and Association with Psychological Adjustment, USA, 285 (16)2094- 2100.

Olweus D. (1995). Bullying at School: What we know and what we can do, Black Well Publishers Ltd, Oxford UK \& Cambridge USA.

Piaget J. (1973). Main Trends in Psychology. London: George Allen \& Unwin Ltd.

Smith P.K. (2000). Bullying and harassment in school and rights of children, J. Child. \& Soc., 14 (4): 294 - 300.

Timmermanis V. and Wiener J. (2011). Social correlates of bullying in children with attention-deficit/hyperactivity disorder. Canadian Journal of School Psychology, 26(4): 301-318.

Vreeman R. C. and Carrol A. A. (2007). A systematic review of school - based interventions to prevent bullying, Arch Pediatr. Adolesc. Med., 161,(1):78-88.

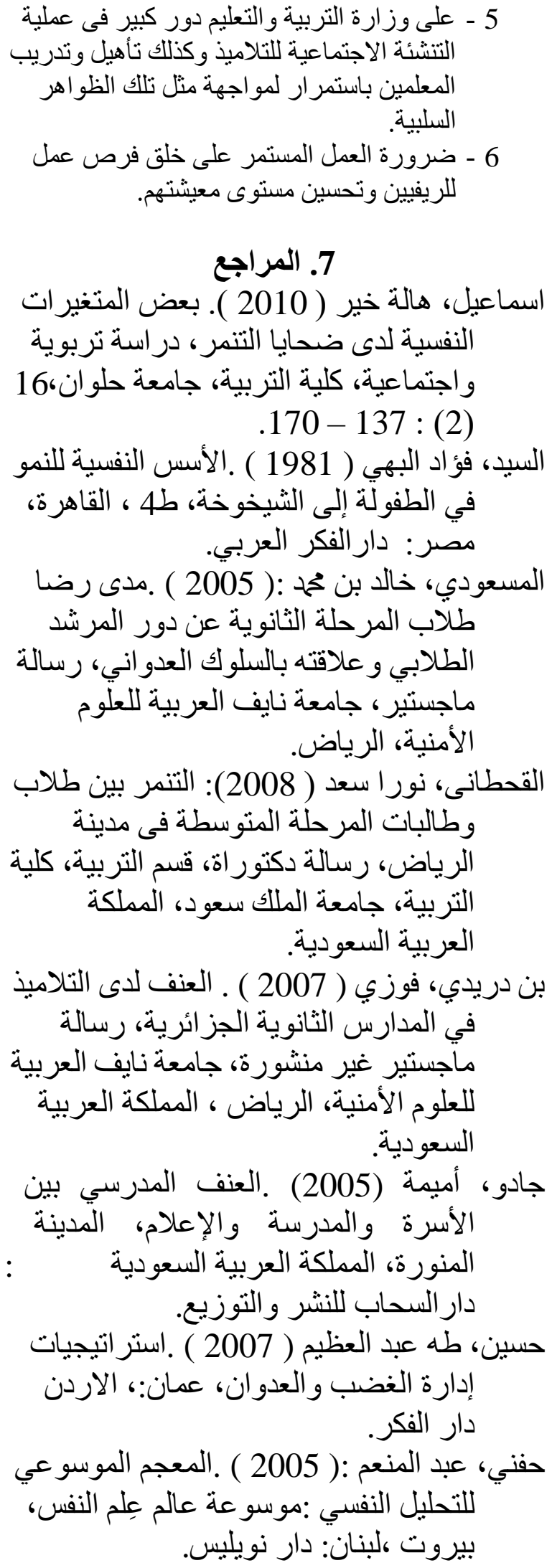




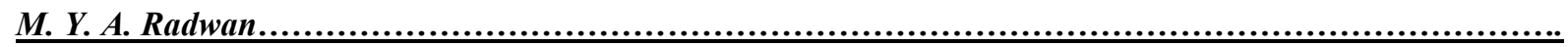

